NBER WORKING PAPER SERIES

\title{
A FISTFUL OF DOLLARS: LOBBYING AND THE FINANCIAL CRISIS
}

\author{
Deniz Igan \\ Prachi Mishra \\ Thierry Tressel \\ Working Paper 17076 \\ http://www.nber.org/papers/w17076
NATIONAL BUREAU OF ECONOMIC RESEARCH
1050 Massachusetts Avenue
Cambridge, MA 02138 \\ May 2011
}

We would like to thank the participants at the IMF Research Brown Bag Seminar, 2009 NBER Summer Institute, Center for Analytical Finance (Indian School of Business) 2009 Summer Research Conference in Finance, World Bank Macroeconomics Seminar, De Nederlandsche Bank 12th Annual Research Conference, Wharton/FIRS/JFI Workshop on the Financial Crisis, IMF 10th Jacques Polak Annual Research Conference, Toulouse School of Economics Conference on the Political Economy of the Financial Crisis, University of Maryland, and 2010 NBER Political Economy Program Meeting for useful discussions and suggestions. Sumit Aneja, Mattia Landoni, and Lisa Kolovich provided excellent research assistance. Nothing contained in this paper should be reported as representing the views of the IMF, its Executive Board, member governments, the National Bureau of Economic Research, or any other entity mentioned herein. The views expressed in this paper belong solely to the authors.

NBER working papers are circulated for discussion and comment purposes. They have not been peerreviewed or been subject to the review by the NBER Board of Directors that accompanies official NBER publications.

(C) 2011 by Deniz Igan, Prachi Mishra, and Thierry Tressel. All rights reserved. Short sections of text, not to exceed two paragraphs, may be quoted without explicit permission provided that full credit, including $\odot$ notice, is given to the source. 
A Fistful of Dollars: Lobbying and the Financial Crisis

Deniz Igan, Prachi Mishra, and Thierry Tressel

NBER Working Paper No. 17076

May 2011

JEL No. G21,P16

\begin{abstract}
Has lobbying by financial institutions contributed to the financial crisis? This paper uses detailed information on financial institutions' lobbying and mortgage lending activities to answer this question. We find that lobbying was associated with more risk-taking during 2000-07 and with worse outcomes in 2008. In particular, lenders lobbying more intensively on issues related to mortgage lending and securitization (i) originated mortgages with higher loan-to-income ratios, (ii) securitized a faster growing proportion of their loans, and (iii) had faster growing originations of mortgages. Moreover, delinquency rates in 2008 were higher in areas where lobbying lenders' mortgage lending grew faster. These lenders also experienced negative abnormal stock returns during the rescue of Bear Stearns and the collapse of Lehman Brothers, but positive abnormal returns when the bailout was announced. Finally, we find a higher bailout probability for lobbying lenders. These findings suggest that lending by politically active lenders played a role in accumulation of risks and thus contributed to the financial crisis.
\end{abstract}

Deniz Igan

International Monetary Fund

Research Department, HQ1-9-700

700 19th St NW

Washington, DC

20431

digan@imf.org

Prachi Mishra

International Monetary Fund

Research Department, HQ1-9-718

700, 19th Street NW

Washington DC

20431

pmishra@imf.org
Thierry Tressel

International Monetary Fund

European Department, HQ1-9-302, 700, 19th Street NW

Washington DC

20431

ttressel@imf.org 


\section{INTRODUCTION}

On December 31, 2007, the Wall Street Journal reported that Ameriquest Mortgage and Countrywide Financial, two of the largest mortgage lenders in the U.S., spent respectively $\$ 20.5$ million and \$8.7 million in political donations, campaign contributions, and lobbying activities from 2002 through 2006. ${ }^{1}$ The sought outcome, according to the article, was the defeat of antipredatory lending legislation that could have mitigated reckless lending practices and the consequent rise in delinquencies. Such anecdotal evidence suggests that the political influence of the financial industry contributed to the 2007 mortgage crisis, which, in the fall of 2008 , generalized in the worst bout of financial instability since the Great Depression. ${ }^{2}$ In spite of the importance of these claims, formal analysis of the political economy factors underlying the crisis has so far remained scant.

This paper asks whether lobbying lenders behaved differently from non-lobbying lenders in the 2000-07 period and how they performed in 2008. To the best of our knowledge, this is the first study that examines empirically the relationship between lobbying by financial institutions and mortgage lending in the U.S. We construct a unique dataset combining information on mortgage

\footnotetext{
${ }^{1}$ Simpson, Glenn, 2008, "Lender Lobbying Blitz Abetted Mortgage Mess," The Wall Street Journal, December 31; available at http://online.wsj.com/public/article_print/SB119906606162358773.html. See also the Financial Times front page coverage of the Center for Public Integrity study linking subprime originators (a large share of which are now bankrupt) to lobbying efforts to prevent tighter regulations of the subprime market (May 06, 2009, "U.S. banks spent \$370 million to fight rules", May 06, 2009, available at: http://www.ft.com/cfms/s/0/a299a06e-3a9f-11de$\underline{8 \mathrm{a} 2 \mathrm{~d}-00144 \mathrm{feabdc} 0 . \mathrm{htm} l \text { ?nclick_check=1). }}$.

${ }^{2}$ For a detailed account of the subprime mortgage crisis, see Gorton (2008a, b) and Diamond and Rajan (2009).
} 
lending activities and lobbying at the federal level. By going through individual lobbying reports, we identify all federal bills targeted by the financial industry lobbying, and focus on the lobbying specifically aimed at rules and regulations of consumer protection in mortgage lending, underwriting standards, and securities laws (henceforth, the "specific issues"). ${ }^{3}$

First, we analyze the relationship between lobbying and ex-ante characteristics of loans originated. We focus on three measures of mortgage lending: loan-to-income ratio (which we consider as a proxy for lending standards), proportion of loans sold (negatively correlated with the quality of loans originated) and mortgage loan growth rates (positively correlated with risktaking). ${ }^{4}$ Controlling for unobserved lender and area characteristics as well as changes over time in the macroeconomic and local lender and borrower conditions, we find that lenders that lobbied more intensively (i) originated mortgages with higher loan-to-income ratios (LIR), (ii) securitized a faster growing proportion of loans originated; and (iii) had faster growing mortgage loan portfolios.

Next, we analyze measures of ex-post performance of lobbying lenders. In particular, we explore whether, at the Metropolitan Statistical Area (MSA) level, delinquency rates - an

\footnotetext{
${ }^{3}$ A sample lobbying report, shown in the appendix Table A2, filed by Bear Stearns and Co. to the Senate's Office of Public Records (SOPR) documents that the company lobbied to change regulations related to mortgage lending standards for the period January-June 2007.

${ }^{4}$ Securitization may weaken monitoring incentives leading to lower-quality loans, hence increasing risk in the financial system. This is why increasing recourse to securitization may be a sign of riskier loan origination. For an analysis of the correlation between fast credit growth and risk, see Dell'Ariccia and Marquez (2006).
} 
indicator of loan performance - were linked to the expansion of lobbying lenders' mortgage lending. We find that faster relative growth of mortgage loans by lobbying lenders during 200006 was associated with higher delinquency rates in 2008. We also carry out an event study during key episodes of the financial crisis to assess whether the stocks of lobbying lenders performed differently from those of other financial institutions. We find that lobbying lenders experienced negative abnormal stock returns at the time of the failures of Bear Stearns and Lehman Brothers, but positive abnormal returns around the announcement of the bailout program. Finally, we examine the determinants of how bailout funds were distributed and find that being a lobbying lender was associated with a higher probability of being a recipient of these funds.

We perform a number of tests to establish robustness of the results. First, we control for lender, MSA, and time fixed effects as well as various lender-MSA-time-varying controls. Second, we conduct falsification tests by exploiting information about lobbying on financial issues that are unrelated to mortgage lending and securitization. Next, we adopt a difference-in-difference strategy to test whether the characteristics of mortgage loans originated by lobbying lenders responded differently to the introduction of anti-predatory lending laws at the state level, than those originated by other lenders. Finally, we adopt an instrumental variable strategy using as instrument the distance between the headquarters of the financial institution and Washington, D.C., which is exogenous and proxies for the cost of lobbying. (Details on these are in Section V.) While these results are robust to a number of controls and alternative estimation strategies, 
we are cautious not to interpret them as a causal link between lobbying activities and mortgage lending. Reverse causality remains a concern: lenders that choose to lobby more intensively may be the risky type to begin with.

Our findings indicate that lobbying was associated ex ante with more risk-taking and ex post with worse performance. This is consistent with some lenders being more likely to benefit from lax regulation: these lenders lobbied more aggressively; the ensuing lax regulatory environment allowed them to engage in riskier lending; and such lending exposed them, directly or indirectly, to worse outcomes during the crisis. Interestingly, the market anticipated lobbying lenders to benefit more from the bailout, and they indeed did, perhaps because they were hit harder by the crisis and/or because they had closer connections to policymakers.

Why are some lenders more likely to benefit from lax regulation? These lenders, for example, may be specialized in catering to riskier borrowers. Or, they may be overoptimistic and may have honestly underestimated the likelihood of an adverse shock. Then, these lenders may have lobbied to signal their private information to the policymaker and prevent tighter regulation that would otherwise have restricted profitable lending opportunities. If lobbying lenders are specialized or overoptimistic, their motive for lobbying is consistent with information-based theories. Alternatively, some lenders may have distorted incentives and might have lobbied to create a regulatory environment that allows them to exploit short-term gains at the cost of longterm profits. An extreme view could be that certain lenders engaged in specialized rent-seeking 
and lobbied to increase their chances of preferential treatment, e.g., a lower probability of scrutiny by bank supervisors or even a higher probability of being bailed out in the event of a financial crisis..$^{5}$ If lobbying lenders are short-termist or lobby to increase their chances of preferential treatment, the motive for lobbying involves moral hazard elements and seems to fit better with theories of rent seeking.

Overall, our findings suggest that the political influence of the financial industry played a role in the accumulation of risks, and hence, contributed to the financial crisis. ${ }^{6}$ But, it is hard to distinguish whether it was information-revealing or rent-seeking that drove lobbying by the financial industry. There is evidence suggesting that lobbying was not motivated solely by information dissemination. Still, the findings fall short of firmly establishing the existence of rent-seeking motives.

The rest of the paper is organized as follows. Section II discusses the related literature. Section III provides some background for the empirical specifications. Section IV describes the dataset. Section V presents the results and Section VI concludes.

\footnotetext{
${ }^{5}$ See Acemoglu (2009) for a similar argument on how financial industry sets its own rules.

${ }^{6}$ See Johnson (2009) for a similar view.
} 


\section{RELATED LiterATURE}

Lobbying is broadly defined as a legal activity aiming at changing existing rules or policies or procuring individual benefits. Private benefits could materialize in the form of preferential access to credit, bailout guarantees, privileged access to licenses, or procurement contracts (Fisman, 2001, Johnson and Mitton, 2003, and Faccio and Parsley, 2006). Building upon the private-interest theories of regulation (Stigler, 1971), research on lobbying has developed into two broad strands: studies that focus on the relationship between lobbying activities and specific policies (see, for instance, Grossman and Helpman, 1994, Goldberg and Maggi, 1999, and Ludema, Mayda, and Mishra, 2010, for the case of trade policy, Facchini, Mayda and Mishra, 2008, for the case of immigration policy, Kroszner and Stratmann, 1998, and Kroszner and Strahan, 1999, for financial services) and those that aim to explore the consequences of lobbying on firm-specific economic outcomes (see, for example, Bertrand et al., 2004, and Claessens et

al., 2008). Issues specific to banking and finance have been studied by, among others, Khwaja and Mian (2005), who find that in Pakistan politically-connected firms obtain exclusive loans from public banks and have much higher default rates; Raddatz and Braun (2009), who present evidence suggesting that politicians provide for beneficial regulation in exchange for a nonexecutive position at a bank in the future, consistent with a capture-type private interest story; and Faccio (2006), who shows that political connections increase firm value. Our study, focusing on lobbying and lending behavior, fits more closely in the second strand. 
Our paper is also related to the emerging literature on the current crisis. While this literature has characterized the relaxation of lending standards and its link to increasing defaults in mortgage markets, evidence on the role of political economy factors remain scarce. ${ }^{7}$ For example, Mian, Sufi and Trebbi (2010a) focus on the consequences of financial crisis showing that constituent and special interests theories explain voting on key bills in 2008. Similarly, Mian, Sufi, and Trebbi (2010b) also analyze voting patterns on few key bills prior to the crisis. In contrast to these papers, we conduct our analysis at the lender-level and study the role of political economy factors in shaping lending behavior during the credit boom and the impact on loan outcomes during the crisis.

\section{BACKGROUND}

Certain firm characteristics may drive both the decision to lobby and lending behavior. Examples of such characteristics include screening technology, underwriting and securitization techniques, specialization of the lender, or the capacity to acquire private information regarding future states of the world. Given such characteristics, certain lenders would make riskier loans, and also have more to gain from a relaxation of the regulatory rules that limit risk-taking. In order to ensure that the regulatory environment remains/becomes lax, these lenders would lobby more

\footnotetext{
${ }^{7}$ For instance, Mayer, Pence and Sherlund (2009) show that no-documentation, no down-payment loans represented a large share of rapidly-growing subprime lending between 2001 and 2006. Mian and Sufi (2009) find that the expansion in subprime lending is highly correlated with the increase in securitization, a finding consistent with distorted incentives. Dell'Ariccia, Igan, and Laeven (2008) provide evidence that areas in which lenders relaxed loan standards more also experienced larger increases in subprime delinquency rates.
} 
intensively against tighter rules and regulations so that they can continue/start making risky loans. Consider a simple example where lender $i$ has a comparative advantage due to a lower cost of securitizing loans. In that case, any regulation that reduces restrictions on securitization activities may generate higher gains for lender $i$ compared to other lenders with higher costs. Hence, the benefits from lobbying for such regulations would be higher for lender $i$. Lender $i$ would therefore lobby more than other lenders at time $t$, even if other lenders may free-ride and also benefit (but to a lesser extent) from lax regulations because of higher gains that accrue to him from lobbying. ${ }^{8}$ If lobbying efforts are successful and the rules are not tightened, this would allow lender $i$ to engage in riskier lending in period $t+1$ and in subsequent periods. Although the new rules would apply to all lenders, lender $i$ has a comparative advantage, which enables him to take more risks under these rules compared to other lenders. Moreover, given their risky portfolios, lender $i$ would be more likely to experience worse loan outcomes and experience higher losses, if hit by adverse shocks.

For example, Citigroup lobbied intensively against H.R. 1051 -- Predatory Lending Consumer Protection Act of 2001 (spending a total of \$3 million over January-June 2002 on this and other issues related to mortgage and securities markets), which aimed to put tighter restrictions on lenders (see Appendix for more details on the bill), and this was never signed into law. Indeed,

\footnotetext{
${ }^{8}$ For example, among the top twenty lenders lobbying on specific issues, six were also among the top ten underwriters of collateralized debt obligations during 2005-08 ("Vampire squished", The Economist, April 24 2010).
} 
during 1999-2006, 93 percent of all the bills promoting tighter regulation were never signed into law. Importantly, two key pieces of legislation to promote lax lending in mortgage markets American Homeownership and Economic Opportunity Act of 2000, and American Dream Downpayment Act of 2003 - were in fact signed into law.

The lax regulatory environment that emerged allowed lenders to engage in riskier lending during 2000-07; and end up with worse outcomes during the crisis. To illustrate with an example, the Wall Street Journal on December $31^{\text {st }}, 2007$ reported

"Data from federal and state campaign-finance records, Internal Revenue Service filings, and the National Institute on Money in State Politics show that from 2002 through 2006, Ameriquest, its executives and their spouses and business associates donated at least $\$ 20.5$ million to state and federal political groups. [...] Ameriquest became a player in the business of lending to lowincome homeowners. The company persuaded many homeowners to take cash out of their houses by refinancing them for larger amounts than their existing mortgages. [...] Home loans made by Ameriquest and other subprime lenders are defaulting now in large numbers."

This mechanism implies that one would observe lobbying in period $t$ to be associated with riskier lending behavior in period $t+1$. The empirical specifications discussed below are based on this mechanism.

Once the financial crisis hit and the government was forced to intervene, the factors that determined who would be bailed out included, e.g., how badly the financial institution was hurt, how systematically important it was, how healthy the balance sheets were, and perhaps how well 
connected the institution was to the politicians. For instance, the Wall Street Journal on January 23rd, 2009 reported

"Troubled OneUnited Bank in Boston didn't look much like a candidate for aid from the Treasury Department's bank bailout fund last fall. [...] Nonetheless, in December OneUnited got a \$12 million injection from the Treasury's Troubled Asset Relief Program, or TARP. One apparent factor: the intercession of Rep. Barney Frank, the powerful head of the House Financial Services Committee. [...] Some powerful politicians have used their leverage to try to direct federal millions toward banks in their home states. "It's totally arbitrary," says South Carolina Gov. Mark Sanford. "If you've got the right lobbyist and the right representative connected to Washington or the right ties to Washington, you get the golden tap on the shoulder"."

The channels highlighted in such anecdotes suggest that one is likely to observe an empirical association between lobbying and ex-post performance as well as the likelihood of bailout in 2008. This motivates our empirical analysis of outcomes during the crisis.

\section{DATA Description}

\section{A. Mortgage Lending}

Mortgage lenders are required to provide detailed information on the applications they receive and the loans they originate under the Home Mortgage Disclosure Act (HMDA). Enacted by Congress in 1975, HMDA data covers a broad set of depository and non- depository financial institutions. Comparisons of the total amount of loan originations in the HMDA and industry sources indicate that around 90 percent of the mortgage lending activity is covered in this database. Our coverage of HMDA data is from 1999 to 2007 to match the lobbying database. 
We collapse the data to MSA-lender level with 378 MSAs and almost 9000 lenders. Then, we construct our variables of interest: loan-to-income ratio at origination, loan securitization rates, mortgage loan growth rate, and the extent of activity by lobbying lenders at the MSA level.

\section{B. Lobbying}

Lobbyists in the U.S. - often organized in special interest groups - can legally influence the policy formation process through two main channels. First, they can offer campaign finance contributions, in particular through political action committees (PACs). These activities have received a fair amount of attention in the literature. ${ }^{9}$ Second, they are allowed to carry out lobbying activities in the executive and legislative branches of the federal government. These lobbying activities, albeit accounting for the bulk of politically-targeted expenditures, have in contrast received scant attention in the literature. Individual companies and organizations have been required to provide a substantial amount of information on their lobbying activities starting with the introduction of the Lobbying Disclosure Act of 1995. Since 1996, all lobbyists (intermediaries who lobby on behalf of companies and organizations) have to file semi-annual reports to the Secretary of the Senate's Office of Public Records (SOPR), listing the name of each client (firm), the total income they have received from each of them, and specific lobbying issues. In parallel, all firms with in-house lobbying departments are required to file similar reports stating the total dollar amount they have spent (either in-house or in payments to external

\footnotetext{
${ }^{9}$ See, for instance, Snyder (1990), Goldberg and Maggi (1999), Gawande and Bandyopadhyay (2000).
} 
lobbyists). Legislation requires the disclosure not only of the dollar amounts actually received/spent, but also of the issues for which lobbying is carried out. Thus, unlike PAC contributions, lobbying expenditures of companies can be associated with very specific, targeted policy areas. Such detailed information is reported by roughly 9000 companies, around 600 of which are in the finance, insurance and real estate (FIRE) industry.

\section{Other Data}

We supplement the information from the lobbying and HMDA databases with MSA-level and state-level data on economic and social indicators such as income, unemployment, population, and house price appreciation. ${ }^{10}$ We also obtain data on delinquent loans from LoanPerformance, a private data company. The stock price return is computed using data from Compustat. The information on the enactment of anti-predatory lending laws is from Bostic et al (2008). ${ }^{11}$ Finally, the data on the 2008 bailout program is based on original records provided by the Treasury through the Office of Financial Stability. ${ }^{12}$

\footnotetext{
${ }^{10}$ Data sources include the Bureau of Economic Analysis (BEA), the Bureau of Labor Statistics (BLS), the Census Bureau, and the Office of Federal Housing Enterprise Oversight (OFHEO).

${ }^{11}$ North Carolina was the first state to pass an anti-predatory lending law in 1999 and other states followed suit. By 2007, all but six states have some form of anti-predatory lending law in place.

${ }^{12}$ The data can be downloaded from http://bailout.propublica.org/main/list/index.
} 


\section{Construction of the Dataset}

\section{Matching Lobbying Firms to Lenders}

The matching of the lobbying and HMDA databases is a tedious task. We use an algorithm that finds common words in lender names to narrow down the potential matches in HMDA of lenders in the lobbying database and then go through these one by one to determine the right match. We examine meticulously the corporate structure of the firms in the lobbying database and that may be a match to a HMDA lender based on our algorithm (see Appendix for more details). We create four lobbying identifiers reflecting several types of matches: (i) exact matches; (ii) matches to parent firm; (iii) matches to affiliated firms; and (iv) matches to subsidiaries. The lobbying variables used in the regressions combine these four variables.

We also consider lobbying expenditures by associations. The list of member firms for each association in the lobbying database is compiled by going on each association's website. A portion of the associations' lobbying expenditures is assigned to each member firm based on the share of its own spending in the total of all members.

\section{Identifying Lobbying Activity Targeted to the Mortgage Market}

Our analysis distinguishes between lobbying activities that are related to mortgage-marketspecific issues from other lobbying activities. We first concentrate only on issues related to the five general issues of interest (accounting, banking, bankruptcy, housing, and financial 
institutions) and then gather information on the specific issues, which are typically acts proposed at the House or the Senate, that were listed by the lobbyists as the main issue for the lobbying activity. ${ }^{13}$ Then, we go through these specific issues one by one and determine whether an issue can be directly linked to restrictions on mortgage market lending. For example, H.R. 1163 of 2003 (Predatory Mortgage Lending Practices Reduction Act) and H.R. 4471 of 2005 (Fair and Responsible Lending Act), regulating high-cost mortgages, are bills that we deem to be relevant to the mortgage market. On the other hand, H.R. 2201 of 2005 (Consumer Debt Prevention and Education Act) and the Sarbanes-Oxley Act of 2002, although in general related to financial services, do not include any provisions directly related to mortgage lending and are not classified as mortgage-market-specific issues.

After classifying all listed issues, we calculate lobbying expenditures on specific issues by splitting the total amount spent evenly across issues. To be more precise, we first divide the total lobbying expenditure by the number of all general issues and multiply by the number of general issues selected. Then, we divide this by the total number of specific issues listed under the five general issues and multiply by the number of specific issues of interest. ${ }^{14}$ In order to illustrate the construction of the final lobbying variable, suppose firm A spends $\$ 300$, and lobbies on 3

\footnotetext{
13 'General issue area codes' are provided by the SOPR and listed in line 15 of the lobbying reports while the 'specific lobbying issues' are listed in line 16. See Appendix for more details on what the reports look like and a full list of general issues as well as that of specific issues selected for the analysis.

${ }^{14}$ For robustness, we adopt an alternative splitting approach that distributes expenditures using as weights the proportion of reports that mention the specific issues of interest. The results remain the same.
} 
general issues (banking and housing - general issues of interest -- and trade - not a general issue of interest); it lists 2 specific issues under banking and housing (H.R. 1163, which is a relevant specific issue and H.R. 2201, which is not relevant). In this example, the final lobbying expenditure variable is calculated as $((300 / 3) * 2) / 2)^{*} 1=\$ 100$.

\section{E. Summary Statistics}

As shown in Table 1, between 1999 and 2006, interest groups have spent on average about $\$ 4.2$ billion per political cycle on targeted political activity, which includes PAC campaign contributions and lobbying expenditures. Lobbying expenditures represent by far the bulk of all interest groups' money spent on targeted political activity (close to 90 percent). Expenditures by FIRE companies constitute roughly 15 percent of overall lobbying expenditures in any election cycle. Approximately 10 percent of all firms that lobbied during this time period were associated with FIRE. Moreover, the lobbying intensity for FIRE increased at a much faster pace relative to the average lobbying intensity over 1999-2006 (Figure 1). Similar inspection of the HMDA database reveals time trends indicating higher LIR and increased recourse to securitization (Figure 2).

Our matching process ends up matching around 250 firms in the lobbying database to one or more lenders in the HMDA database, corresponding to roughly 40 percent of FIRE firms that lobby. In the final MSA-lender-year level dataset, lenders that lobby on specific issues comprise 
around 11 percent of the observations. Lobbying was performed by the lender itself in 25 percent of these observations and by the parent financial institution, affiliated firms, and subsidiaries in 65,23 , and 5 percent respectively. This suggests that it was mainly the parent firms, which are likely to be large, national financial institutions or holding groups, that lobbied on specific issues relevant for their subsidiaries. In terms of magnitudes, the matched lenders spent in total roughly half a billion dollars for lobbying on specific issues during 1999-2006. Lobbying expenditures by lenders' associations during the same period remained comparatively small (8 percent of total spent).

As shown in Figure 3, lobbying lenders (i) tend to be larger either by assets or market share, (ii) less likely to be HUD-regulated, (iii) more likely to be subprime, and (iv) cater to richer borrowers. In terms of measures of lending, they had (i) slightly higher LIRs, (ii) lower tendency to securitize, and (iii) faster growing loan portfolios. In addition, lobbying lenders were significantly more likely to be bailed out. ${ }^{15}$ In the following section, we examine these relationships rigorously. Summary statistics on the variables used in the empirical analysis are shown in Table 2.

\footnotetext{
${ }^{15}$ Sixteen of the twenty lenders that spent the most on lobbying between 2000 and 2006 received funds provided by the government under the TARP. In total, lenders that lobbied on specific issues received almost 60 percent of the funds allocated.
} 


\section{EMPIRICAL ANALYSIS}

This section presents the empirical specifications and regression results, based on the mechanisms discussed in Section III. First, we analyze the relationship between lobbying and the ex-ante characteristics of loans originated (the loan-to-income ratio; the proportion of loans sold; the growth rate of loans originated). Second, we explore the relationship between lobbying and ex-post outcomes (delinquency rates; stock returns during the crisis; likelihood of being bailed-out).

\section{A. Empirical Analysis of Loan-to-Income Ratio}

We estimate the following panel equation:

$$
y_{i m t}=\alpha+\beta \cdot l_{i}+\lambda \cdot Z_{i m t}+v_{m}+\pi_{t}+v_{m} * \pi_{t}+\varepsilon_{i m t}
$$

where $y_{i m t}$ is a measure of loan characteristics for lender $i$, in MSA $m$ during year $t . l_{i}$ is a dummy for lenders that lobby the federal government on specific issues. ${ }^{16} Z_{\text {imt }}$ denotes a set of control variables at the lender-MSA level. $v_{m}$ and $\pi_{t}$ denote a set of MSA and year fixed effects respectively. $v_{m} * \pi_{t}$ captures the effect of all MSA-time varying factors on loan characteristics,

\footnotetext{
${ }^{16}$ Recall from Section IV that lobbying activities are reported at the lender level and do not vary across MSAs.
} 
which are constant across lenders. MSA fixed effects control for any time-invariant MSA level omitted variable, which could be correlated with lobbying and also affect loan characteristics. In addition, the interaction between MSA and year effects, allows us to capture any time-varying MSA characteristics. Time effects control for global shocks affecting all lenders and areas equally. The parameter of interest is $\beta$, which captures average differences in mortgage loan characteristics between lenders that lobby and lenders that do not lobby. ${ }^{17}$

Our main variable capturing ex-ante characteristics is the loan-to-income ratio (LIR) averaged at the lender-MSA level. This measure is a simplified version of a commonly used indicator, debtto-income ratio, to determine whether a borrower can afford a mortgage loan. Lenders usually require that mortgage payments cannot exceed a certain proportion of the applicant's income. ${ }^{18}$ As the maximum proportion allowed increases, the burden of servicing the loan becomes harder and the default probability potentially increases. We compute the LIR as a proxy for such limits required by the lender and interpret increases in this ratio that are not explained by lender, location characteristics or by time fixed effects as a loosening in lending standards.

\footnotetext{
${ }^{17}$ Free-riding problems may bias the estimated coefficient if lenders also benefit from lobbying activities of others. However, the bias will be small if the externality is common to all other lenders, as the average effect of the externality will be absorbed by year fixed effects (or by MSA-year fixed effects if the externality to other lenders depends on the MSAs in which a lender is active).

${ }^{18}$ See, for instance, Sirota (2003).
} 
Table 3 presents the regression results of the LIR of originated loans on a dummy variable for lenders lobbying on specific issues. The coefficient on this dummy variable is positive and statistically significant at the 1 percent level in all the specifications, establishing that mortgage loans originated by lenders lobbying on specific issues have higher LIR on average. This finding remains unaffected when controlling for observable MSA and lender-MSA characteristics (Column (2)). Lender-MSA level control variables ensure that the estimated coefficient on the dummy for lobbying lenders does not reflect characteristics such as the size of the lender (proxied by log of assets), the market power of the lender in a particular MSA (proxied by its market share), or other factors proxying for observable and unobservable characteristics of a lender's pool of applicants such as (i) whether the lender focuses on community development mortgages or has a brokerage-type business model (proxied by a dummy for HUD-regulated lenders), (ii) whether the lender specializes in subprime lending, and (iii) the average income of applicants of loans originated by the lender in a particular MSA. Moreover, the size of the coefficient increases as control variables are added to the regression suggesting that omitted variables at the MSA level and at the lender-MSA level may have resulted in attenuation bias.

Adding MSA, year, and MSA-year fixed effects does not affect the magnitude or the significance of the estimated coefficients (Columns (4) and (5)). This set of fixed effects confirm that our results do not reflect unobserved, either time-invariant or time-varying MSA characteristics, or time effects common to all MSAs. Importantly, MSA-year interactions in column (5) guarantee that the estimated effect is not biased due to, for example, the average quality of the borrower 
pool at the MSA level. If the relationship between lobbying and loan characteristics reflected mainly a specialization of lenders, we should expect the estimated coefficient to become smaller and insignificant when we include controls for lender characteristics such as whether she is regulated by the HUD or is classified as a subprime lender by the HUD. We find, on the contrary, that the estimated coefficient becomes larger. This evidence casts some doubt that lender specialization could be the explanation for the difference in loan characteristics between lobbying lenders and other lenders.

The magnitude of the difference in LIR between lobbying lenders and other lenders is not trivial. The estimated coefficient of 0.15 in Column (5) implies that the average LIR of mortgages originated is about 0.15 points higher for lobbying lenders than for other lenders. This is about 8 percent of the average LIR of 1.97 in the complete sample.

The estimated relationship between LIR and the lobbying decision may reflect a general propensity to lobby, e.g., in order to gain access to policymakers to get private benefits, rather than a desire to influence specific rules. Then, we would expect to obtain a similar result for lenders that lobby on financial sector issues that are unrelated to mortgage markets. To carry out this falsification exercise, we create a dummy variable for lenders lobbying on issues that are not related to mortgage lending and securitization, e.g., consumer credit and security of personal information, financial services other than mortgage lending, anti-money laundering (henceforth, the "other issues"). We repeat our preferred specification presented in Column (5), Table 3 by adding the new dummy. Column (6) displays the results. We find that the dummy for lobbying 
on specific issues has a positive and significant coefficient while the dummy for lobbying on other issues has a negative and significant sign. This suggests that the desire to influence specific rules was one of the drivers of lobbying efforts.

Second, we estimate the following panel equation:

$$
y_{i m t}=\alpha+\delta \cdot(\ln L O B A M)_{i t-1}+s_{i}+v_{m}+\pi_{t}+v_{m} * \pi_{t}+\lambda \cdot Z_{i m t}+\varepsilon_{i m t}
$$

where outcome variables are the same as in Equation (1), $(\ln L O B A M)_{i t-1}$ is the logarithm of the amount of lobbying expenditures by lender $i$ during year $t-1 .{ }^{19} s_{i}$ denotes a set of lender fixed effects which capture the effect of all lender-specific time-invariant factors on loan characteristics. Note that lender fixed effects account for any unobserved lender-specific omitted variable that does not vary over time. The preferred specification includes lender, MSA, year effects and MSA-year interactions; lobbying expenses only change at the lender-year level, so we cannot include lender-year interactions. The advantage of using the level of lobbying expenditures is that the time variation in lobbying amounts allows us to introduce lender fixed effects, and therefore to identify the coefficient of interest on the within dimension, in contrast to Equation (1) where the coefficient of the lobbying dummy reflects systematic differences between firms.

${ }^{19} L O B A M$ is assumed to be equal to $\$ 1$ when a lender does not lobby. 
Table 4 reports regressions of LIR on lobbying expenditures. The coefficient on the lobbying amount is positive and significant at a 1 percent level for various sets of fixed effects and control variables. In specifications including lender fixed effects (Columns (3) to (5)), the coefficient of interest therefore reflects a correlation over time between the LIR and the lobbying amounts for lobbying lenders only. Hence, any time-invariant lender-specific factors - such as a superior screening technology - affecting both the decision to lobby and lending standards are absorbed by the lender fixed effects. Another concern is that there may be shocks common to all lenders, which we address by introducing time dummies. Columns (2) to (5) show that the coefficient remains significant. Furthermore, Columns (4) and (5) include MSA-year interactions controlling for time-varying local conditions faced by lenders. ${ }^{20}{ }^{21}$ The range of estimated coefficient suggests that a one standard deviation rise in lobbying expenditures is associated with

\footnotetext{
${ }^{20}$ We conduct further robustness tests for: (i) clustering at MSA level, (ii) exclusion of outliers, (iii) alternative split of total expenditures into specific and non-specific issues based on share of reports, (iv) alternative measure of lobbying expenditures, scaled by the importance of the regulations for which the firm lobbies, giving more weight to lobbying for bills that appear more often in the lobbying reports, (v) using lobbying expenditures scaled by assets, and (vi) taking into account lobbying expenditures by bankers' associations. The main result that more lobbying is associated with higher LIR remains unaltered (see Table A4 in the Appendix).

${ }^{21}$ Another potential concern could be that there are lender-specific time trends that drive the propensity of a lender to take risk as well as to lobby. To address this concern, we augment Equation (2) with $s_{i}{ }^{*} t$ and the coefficient on lobbying remains positive and statistically significant at the 1 percent level.
} 
a $0.02-0.11$ points rise in LIR. This constitutes $1-5$ percent of the average LIR of 1.97 in the complete sample. ${ }^{22}$

\section{B. Difference-in-Difference Estimations using State-Level Laws}

We make use of difference-in-difference estimations exploiting across-state variation in lending laws to uncover whether the existence of anti-predatory lending laws at the state level have differential effects on the mortgage lending behavior of lenders that lobby relative to those that do not lobby. ${ }^{23,24}$ The hypothesis is that lobbying lenders were originating riskier loans than other lenders in the absence of anti-predatory lending laws. Therefore, when a law comes into effect at the state level they tighten their loan terms more than other lenders to meet the minimum legal requirements. In one sense, this is a mirror image of the relationship between lobbying and lending we explored in the earlier subsections: when tighter federal regulations fail to pass or lax federal regulation comes to effect, lobbying lenders increase LIR more; here, when tighter state regulation comes into effect, we expect lobbying lenders to decrease LIR more.

\footnotetext{
${ }^{22}$ For a 10 percent increase in $L O B A M$, the outcome variable changes by $d y_{i m t}=\delta * d \ln L O B A M_{i m t-1}=\delta * \ln \left(L O B A M_{i m t-1} / L O B A M_{i m t-2}\right) \approx \delta * 0.1$.

${ }^{23}$ Keys et al. (2009) use a similar identification strategy based on state lending laws in their analysis of securitization and monitoring incentives.

${ }^{24}$ A potential concern is that state lending legislation efforts may be affected by the financial industry's overall lobbying activities, however, lobbying at the federal level is less likely to influence any individual state's decision to pass a law. Moreover, what we are interested in is the differential response of lobbying versus non-lobbying lenders to the regulatory changes once a law comes into effect rather than the causal effect of the law.
} 
We estimate the following difference-in-difference panel equation:

$$
\begin{aligned}
& y_{i m t}=\alpha+\beta \cdot A P L_{s t}+\delta \cdot(\ln L O B A M)_{i t-1}+\phi \cdot(\ln L O B A M)_{i t-1} \cdot A P L_{s t}+\gamma \cdot X_{m t}+\lambda \cdot Z_{i m t} \\
& +s_{i}+v_{m}+\pi_{t}+\varepsilon_{i m t}
\end{aligned}
$$

$A P L_{s t}$ is a dummy equal to 1 if there exists an anti-predatory lending law in state $s$, where MSA $m$ is located, at time $t .^{25} X_{m t}$ denotes a set of MSA-year varying controls.

As shown in Table 5, the coefficient on the interaction term between the dummy for an antipredatory lending law and lobbying intensity is negative and significant at the 1 percent level in Columns (2)-(4). This result is consistent with the hypothesis that lobbying lenders, at the margin, raise their lending standards more than other lenders when anti-predatory lending laws are in place. This implies that these laws happened to be more binding for lobbying lenders and that, before the law came into place, lobbying lenders were more likely to have engaged in risky lending practices.

The result is robust to including lender, MSA and year fixed effects, and when we control for MSA-time, lender-time or lender-MSA-time level observable characteristics. In addition, the overall effect of an anti-predatory lending law being in place, evaluated at the average lobbying

\footnotetext{
${ }^{25}$ In some cases, a single MSA contains areas in several states. Then we assume that the MSA has a law in place if any one of the states does.
} 
expenditures in the sample, is $\beta+\phi \cdot(\overline{\ln L O B A M})<0$. This suggests that LIR is lower in MSAs that belong to states with anti-predatory lending laws in place.

\section{Evidence on Lobbying and Securitization and Mortgage Credit Growth}

In addition to LIR, we use as two other dependent variables that provide additional information on lending practices: (i) the proportion of mortgages securitized and (ii) the annual growth rate in the amount of loans originated. Recourse to securitization has been shown to weaken monitoring incentives; hence, a higher proportion of securitized loans can be associated with lower credit standards (see Keys et al, 2009, for evidence that securitization leads to less monitoring and worse loan performance). Next, fast expansion of credit could be associated with lower lending standards for several reasons. First, if there are constraints on training and employing loan officers, increased number of applications will lead to less time and expertise allocated to each application to assess their quality (see Berger and Udell, 2004). Second, in a booming economy, increasing collateral values will increase creditworthiness of intrinsically bad borrowers and, when collateral values drop during the bust, these borrowers are more likely to default (see Kiyotaki and Moore, 1997). Third, competitive pressures might force lenders to loosen lending standards and extend loans to marginal borrowers in order to preserve their market shares.

Table 6 (Columns (1) and (2)) shows that the proportion of mortgage loans securitized is positively correlated with lobbying expenditures within lenders. Hence, securitization increased 
faster over time for lobbying lenders than for other lenders. The result is robust to the inclusion of lender, MSA and year fixed effects and MSA-year interactions. Moreover, Columns (3) and (4) show that lobbying is also positively correlated with the growth of mortgage lending. This result is significant at the 1 percent level, suggesting that lobbying lenders, through faster expansion of their mortgage loan portfolios, tend to lend more aggressively. In terms of magnitudes, a one standard deviation increase in lobbying expenditures is associated with an 11 percent increase in the proportion of loans securitized and a 3 percentage point rise in credit growth.

\section{Mortgage Lending by Lobbying Lenders and Delinquency Rates}

We relate delinquency rates in 2008 in a given area (recall from Section IV that our data on delinquency rates are at the MSA level) to the growth of lobbying lenders' market share during 2000-06. Our explanatory variable measures the expansion of mortgage loans by lobbying lenders relative to the expansion of such loans by all lenders during the period of interest. Specifically, we estimate the following cross-sectional empirical model:

$$
d r_{m, 2008}=\alpha+\theta \cdot \overline{g m s h}_{m}+\mu \cdot X_{m}+\eta \cdot Z_{m}+\varepsilon_{m}
$$

where $d r_{m, 2008}$ is the MSA level delinquency rate as of 2008, $\overline{g m s h}_{m}$ is the average annual growth rate of the total market share of lobbying lenders in the MSA over 2000-06, $X_{m}$ is a set 
of MSA characteristics and $Z_{m}$ is a set of mortgage loan characteristics and lender characteristics averaged at the MSA level. The coefficient of interest $\theta$ captures the partial correlation between delinquency rates and the growth rate of mortgage lending by lobbying lenders relative to nonlobbying competitors.

Regression results reported in Table 7 show that delinquency rates in 2008 were significantly higher in MSAs in which mortgage lending by lobbying lenders has expanded relatively faster than mortgage lending by other lenders. This result is robust to the inclusion of various MSAlevel characteristics, including characteristics of the mortgage market such as the share of subprime loans and the number of lenders (Column (1)). These control variables ensure that the correlation does not reflect the fact that lobbying lenders may have expanded faster in areas that ex post suffered more from the decline in house prices, or that had a higher proportion of risky borrowers, or that were affected more by the economic downturn. The exclusion of states in which the housing boom-bust cycle was more severe (Arizona, California, Florida, and Nevada) ensures that mortgage market outcomes of these four states are not driving the results (Column (2)). The estimated effect is economically significant: a one standard deviation increase in the relative growth of mortgage loans of lobbying lenders is associated with almost a 1.5 percentage point increase in the delinquency rate.

We perform two tests to address concerns that, even if we included many control variables, omitted factors could still be driving the correlation between delinquency rates and the expansion 
of lobbying lenders. First, as in the analysis of loan characteristics at origination, we make use of a falsification test to show that the expansion of mortgage lending by lobbying firms does not merely reflect lender characteristics that may be correlated with a general propensity to lobby. Indeed, we find no statistically significant relationship between delinquency rates and the relative expansion of mortgage lending by lenders that lobbied on other issues (Column (3), Table 7).

Second, we develop an instrumental variable strategy. As a first instrument, we consider the combined 1998 market share in the MSA of lenders who lobbied on specific issues, in which each lender's initial market share is weighted by the distance between each lender's headquarters and Washington, D.C. This instrument is valid if (i) the initial presence of a lender in a MSA is predetermined and is not correlated with lending conditions that prevailed in this MSA in the following years; (ii) the distance between a lender's headquarters and Washington, D.C. - a proxy for certain costs of lobbying - is uncorrelated with lending conditions in any specific MSA. The correlation between this instrument and the endogenous variable is negative (first stage results are available upon request), potentially because a smaller initial market share coupled with low cost of lobbying results in faster subsequent growth of lobbying lenders in that area. We consider a second instrument defined in a similar way (initial market share weighted by the distance variable), but using instead the initial market share of lenders lobbying on other issues. The sign of the correlation between this instrument and the endogenous variable is positive possibly because, in MSAs in which these other lenders have a larger initial presence, 
lenders lobbying on specific issues may intensify their lobbying and lending activities and gain market share even more when these other lenders have a higher cost of lobbying and a high initial market share.

Regression results confirm the conclusions of our OLS estimations (Column (4), Table 7). When instrumenting the variable of interest, the coefficient increases significantly, suggesting that there might be an attenuation bias in the OLS estimates. Moreover, the Hansen $\mathrm{J}$ test does not reject the validity of the instruments. Furthermore, to allay concerns of weak instrument bias, we also make use of the LIML estimator known to be more robust to weak instrument bias and confirm the 2SLS results (Column (5), Table 7). All in all, the evidence is suggestive of a causal relationship between the expansion of mortgage lending by lobbying institutions and subsequent delinquency rates.

\section{E. Stock Price Returns during the Crisis}

Following the methodology developed in recent studies assessing the value of political connections (Fisman, 2001; Faccio, 2005; and Fisman et al., 2006), we perform an event study around the major events of the financial crisis and ask whether lenders that lobbied on specific issues experienced abnormal stock market returns during the month the event took place. ${ }^{26} \mathrm{We}$ consider the following empirical specification:

\footnotetext{
${ }^{26}$ There exists a key difference with the approach of these papers that quantify the value of political connections. They conduct the event study around periods of news under the assumption that these news a priori specifically affect politically connected firms only, while other firms should not be directly impacted, and confirm the initial
} 


$$
R_{i e}=\alpha+\beta \cdot l_{i}+\gamma \cdot X_{i}+\varepsilon_{i}
$$

where $R_{i e}$ is the ex-dividend monthly return on firm $i$ 's stock over the event period $e, l_{i}$ is a dummy for financial institutions that lobby on specific issues during 1999-2006, $X_{i}$ is a set of control variables, and $\varepsilon_{i}$ is a residual. ${ }^{27}$ We use the market- and risk-adjusted return defined as the stock return adjusted for the predicted return based on the CAPM. ${ }^{28}$ If lobbying was systematically related to risk-taking and the quality of loans made, then we would expect lobbying lenders to have lower abnormal returns during negative events and higher abnormal returns during positive events.

We consider three major events of the crisis, namely, the collapse of two key investment banks (negative events) and the government's ultimate response to the turmoil in the financial system (a positive event). The event dates are: (i) March 11-16, 2008 (JP Morgan acquired Bear Stearns after Fed provides $\$ 30$ billion in non-recourse funding; Fed expanded liquidity provision), (ii)

\footnotetext{
hypothesis. In our case, however, all firms are a priori potentially affected by the market news, but we show that the effect of news on market value varies systematically across financial intermediaries according to lobbying behavior in a direction that is consistent with our hypothesis.

${ }^{27}$ Monthly stock returns are computed from the end of the previous month to the end of the month considered.

${ }^{28}$ The market- and risk-adjusted return is defined as: Abnormal_return $i e=R_{i e}-K_{i t}$ where

$K_{i t}=a_{i}+b_{i} \cdot R_{m t}$ where $a_{i}$ and $b_{i}$ are firm-specific coefficients estimated over 2007-08, and $R_{m t}$ is the market return (proxied by the return on the stock market index of banks in the S\&P500). The results presented in this section are robust if we consider (i) simple stock return or (ii) the mean-adjusted return, defined as the stock return of firm $i$ adjusted for its mean over 2007-08.
} 
September 15-16, 2008 (Lehman Brothers filed for bankruptcy while AIG was bailed out), and (iii) October, 14, 2008, when the bailout program was announced.

Regression results are reported in Table 8. Our analysis indicates that lenders that lobbied on specific issues experienced negative abnormal returns during the collapse of key financial institutions suggesting that these lenders were significantly more exposed, directly or indirectly, to bad mortgage loans. Finally, lobbying lenders experienced positive abnormal returns during the announcement of the TARP potentially implying that the market anticipated lobbying lenders to be more connected to the policymakers and have higher chances of benefiting from the bail out. Note that the estimated coefficient on the lobbying dummy does not merely reflect the effect of a specialization of the lender considered (as proxied by the subprime dummy or by total mortgage loans originated in proportion to total assets). We also control for the size and exposure to mortgages of the lender as a proxy for size, but find no significant effect on abnormal stock returns.

The coefficient of interest is statistically significant at conventional levels for all three events. Moreover, the estimated effects are very large. Lobbying financial institutions lost on average 21 percent during the 2008 events. The differential loss of value is even more impressive during the Lehman failure: a 37 percent additional loss of value when returns are adjusted for the market correlation. The results suggest that these financial institutions were significantly more exposed 
to bad mortgage loans than other financial institutions. However, these institutions gained 27 percent when TARP was announced.

\section{F. Lobbying and Bailout}

In this section, we examine whether the likelihood of getting bailed out in 2008 is correlated with lobbying in 2000-06. We estimate the following regression specification:

$$
\text { Bailout }_{i, 2008}=\alpha+\beta L O B B Y_{i, 2000-06}+\mu \cdot X_{i}++\varepsilon_{i}
$$

where Bailout $_{i, 2008}$ is a dummy that is 1 if the lender got funds under TARP or the amount of TARP funds received by lender (in $\operatorname{logs}$ ). $L O B B Y_{i, 2000-06}$ is either a dummy equal to 1 if the lender lobbied on specific issues in any year between 2000-06 or the sum of lobbying expenditures during 2000-06. The specification controls for a number of lender level characteristics which include proxies for their size, proxies for specialization (whether they are regulated by HUD, or whether they are classified as subprime lenders by HUD), the average income level of the borrowers and importantly the average LIR of the loans they originated over 1999-2006 as an additional control for the riskiness of their mortgage loan portfolio over this period.

The regression results are shown in Table 9. We find that lenders who lobbied were more likely to be bailed out (Columns (1) and (2)) and received larger amounts of TARP funds (Columns (3) 
and (4)). Lastly, lenders that spent more on lobbying activities received a bigger piece of the cake (Columns (5) and (6)). In terms of magnitude, lobbying lenders are 7 percent more likely to be bailed out (for comparison, less than 1 percent of the lenders in the dataset were bailed out), yet a one standard deviation increase in lobbying expenditures is associated with a relatively small 0.4 percent increase in the TARP funds received. Another interesting finding is that larger lenders were more likely to be bailed out as suggested by the positive and statistically significant coefficient on the two proxies for size - assets and market share. This is in line with the too-bigto-fail argument. ${ }^{29}$

\section{G. Discussion of Results}

To summarize, lobbying was associated ex ante with more risk-taking at mortgage origination as measured by higher LIR, higher securitization rates, and faster mortgage credit expansion. Ex post, delinquency rates were higher in areas in which lobbying lenders expanded their mortgage lending more aggressively. Moreover, lobbying lenders had negative abnormal stock returns during the Bear Stearns rescue and the collapse of Lehman Brothers, but positive abnormal stock returns around the date the bailout package was announced. Finally, lobbying lenders were more likely to be bailed-out than other lenders.

\footnotetext{
${ }^{29}$ The results shown in Table 9 are estimated by OLS; they are also robust to using probit. These results should be interpreted with caution as unobserved lender-level characteristics could be driving our results.
} 
While these results should not be interpreted as establishing a causal link between lobbying and mortgage lending, taken together, they are consistent with the stories outlined in Section III. Certain lenders were more likely to benefit from lax regulation. These lenders lobbied more aggressively; the ensuing lax regulatory environment let them take more risks and exposed them to worse outcomes during the crisis. In addition, the evidence is consistent with the market anticipating that lobbying lenders would be more likely to benefit from the bailout and they indeed did.

There may be several characteristics that determine whether lenders are more likely to benefit from lax regulation. First, these lenders may be specialized, e.g., in catering to borrowers with lower income levels or in areas with higher average property prices. They may lobby to signal their information on special lending opportunities, thereby preventing tighter regulation that would otherwise limit growth in their particular segments. In the empirical analysis, we include explicit controls, e.g., whether the lender is subprime or is regulated by HUD, size of the lender (which may be another proxy for specialization if specialized lenders are smaller), and the average income level of borrowers, to capture certain kinds of specialization effects. The coefficient on lobbying variable remains significant, so the results are not much likely to be driven by lenders specialized along these dimensions (although they may still be driven by specialization along other dimensions). 
Second, certain lenders may be overoptimistic and may have underestimated the likelihood of an adverse event affecting the mortgage market more than other financial intermediaries did. ${ }^{30}$ Owing to a genuine and systematic underestimation of default probabilities, overoptimistic lenders might have lobbied to inform the policymaker of the "true" state of the world and prevent a tightening of lending laws. Then, they may have taken more risks ex ante and had higher exposures to bad loans ex post. Interestingly, we find that the difference in LIR of originated loans between lobbying lenders and other lenders was even larger during 2005-07, implying that lobbying lenders relaxed their lending standards more during this period (see Column (7) of Table A4 in the Appendix). It is not clear why lobbying lenders would have become even more overoptimistic during the years when signs of stress in the housing market were becoming visible. Moreover, one would expect that if lobbying lenders were genuinely expecting better prospects for mortgage loans, they would have securitized at a slower pace in order to keep these loans in their balance sheets rather than shift risks, contrary to what we find in the data.

Third, certain lenders may have a greater desire or ability to exploit high short-term gains associated with riskier lending strategies. These lenders lobby to prevent a tightening of lending laws that may reduce the benefits associated with short-termist strategies emphasizing short-term

\footnotetext{
${ }^{30}$ For example, rating agencies and sponsors severely underestimated the probability of default and loss given default when assigning ratings to mortgage-backed securities (Calomiris, 2008).
} 
gains over long-term profit maximization. Short-termism can lead to moral hazard and result in more risk-taking ex ante and worse performance ex post. ${ }^{31}$

A more cynical alternative story could be that certain lenders lobby the policymaker to increase their chances of preferential treatment, e.g., a lower probability of scrutiny by bank supervisors or a higher probability of being bailed out in the event of a financial crisis. This in turn could lead to moral hazard and induce lenders to originate loans that would appear riskier ex ante. ${ }^{32}$ Assuming all else equal, these loans would have a higher probability of default ex post. On the one hand, lobbying on any issue should establish connectedness, increase chances of getting preferential treatment and enhance incentives to take more risk. However, as discussed above (Table 3), lobbying on other issues was not significantly associated with risk-taking, which weakens the case for such motives for lobbying. On the other hand, there is evidence that large lenders were the ones lobbying more aggressively and ultimately getting bailed out with a higher probability. These suggest that lobbying might have been driven in part by too-big-to-fail concerns and, in turn, by expectations of preferential treatment.

\footnotetext{
${ }^{31}$ Short-termism in executive compensation is explored theoretically by, among others, Bolton, Scheinkman and Xiong (2006), while empirical evidence on whether distorted incentives contribute to excessive risk-taking is mixed (Agarwal and Wang, 2009; Cheng, Hong, and Scheinkman, 2010; Fahlenbrach and Stulz, 2009). In policy circles, flaws in compensation contracts have become a key issue since the crisis (see, for instance, a speech by the Fed Chairman Bernanke at http://www.federalreserve.gov/newsevents/speech/bernanke20091023a.htm ).

${ }^{32}$ See Tressel and Verdier (2009) for a model of regulatory forbearance of banks emphasizing this moral hazard channel.
} 
It is empirically extremely difficult to pin down the most likely motivation for the financial industry's lobbying during our sample period. Ultimately, we do not know the exact activities on which lobbying expenditures are spent. If lobbying lenders are specialized or overoptimistic, their motive for lobbying appears to be consistent with information-based theories, which assert that lobbying firms have better information than the policymakers and partly reveal their information by endogenously choosing their lobbying effort (Potters and van Winden, 1992; Lohmann, 1995; Grossman and Helpman, 2001). If lobbying lenders are short-termist or lobby to increase the chances of preferential treatment, their motive for lobbying seems to fit better with theories of rent seeking, where lobbying firms compete for influence over a policy by strategically choosing their contribution to politicians (Bernheim and Whinston, 1986; Grossman and Helpman, 1994).

While we cannot firmly tell apart alternative theories of information dissemination and rent seeking, we can try to distinguish the channels through which lobbying was associated with lending: relaxation of rules or earning preferential treatment. Specifically, lenders differ in their capacity or willingness to take risks: some lenders are the risky type and are more likely to benefit from (i) relaxation of lending rules, and (ii) discretion of regulators favoring them over others, e.g., less supervision or perceived insurance against adverse outcomes. These risky lenders lobby more and they take more risk (i) if lobbying efforts are successful and the lending rules remain/become lax, and (ii) if they are under less scrutiny or have insurance. 
To what extent ex-ante risk-taking by lobbying lenders is explained by changes in regulations, that benefits many lenders (free riding), or by anticipation/realization of firm-specific favors? We do a simple test which can help us quantify the relative magnitudes of these two channels. First, taking LIR in 1999 (after purging the MSA effects) as an indicator of initial risk bearing, we label the lenders in the top quartile as the risky type. Let $\Delta L I R_{R}^{L-N L}$ be the difference in the LIR during 2000-07 (after purging the MSA and year effects) of the risky type between the lobbying and non-lobbying lenders. Since the lenders we are comparing are the same type and, hence, benefit the same way from the same rules, we do not expect to observe any difference in risk-taking due to the effect of lobbying on lending rules. Therefore, any difference can be attributed to expectation/realization of firm-specific benefits associated with lobbying.

Similarly, let $\triangle L I R N L \quad R-L R$ be the difference in the LIR during 2000-07 (after purging the MSA and year effects) of non-lobbying lenders between the risky and less-risky types. With relaxation of rules, non-lobbying risky lenders free-ride and increase their LIR while the lessrisky types do not have the capacity to take as much risk. So, any difference can be attributed to free-riding. 
In the end, we compare $\Delta L I R_{R}^{L-N L}$ and $\Delta L I R_{N L}^{R-L R}$ to evaluate the relative magnitudes of the two channels. We find that both differences are positive and statistically significant at the 1 percent level. Moreover, they are roughly the same magnitude with $\Delta L I R_{R}^{L-N L}=0.14$ and $\Delta L I R_{N L}^{R-L R}=$ 0.16 ( 7 and 8 percent of the sample average LIR, respectively). Consequently, the association we establish between lobbying and lending in our sample period appears to be driven equally by both channels: changes in rules and preferential treatment.

\section{Conclusion}

This paper studies the relationship between lobbying by financial institutions and mortgage lending during 2000-07. To the best of our knowledge, this is the first study documenting how lobbying may have contributed to the accumulation of risks leading the way to the current financial crisis. We carefully construct a database at the lender level combining information on loan characteristics and lobbying expenditures on laws and regulations related to mortgage lending and securitization. We show that lenders that lobby more intensively on these specific issues engaged in riskier lending practices ex ante, suffered from worse outcomes ex post, and benefited more from the bailout program.

While pinning down precisely the motivation for lobbying is difficult, our analysis suggests that the political influence of the financial industry contributed to the financial crisis by allowing risk accumulation. Therefore, it provides some support to the view that the prevention of future 
crises might require a closer monitoring of lobbying activities by the financial industry and weakening of their political influence. However, the precise policy response would depend on the true motivation for lobbying. Specialized rent-seeking for preferential treatment such as bailouts would require curtailing lobbying as a socially non-optimal outcome. Distorted incentives due to short-termism linking risky lending and lobbying would require public intervention in the design of executive compensation. If, however, lenders lobbied mainly to inform the policymaker and promote innovation, lobbying would remain a socially beneficial channel to facilitate informed decision making. 


\section{References}

Acemoglu, D., 2009, “The Crisis of 2008: Structural Lessons for and from Economics”, mimeo, MIT.

Agarwal, S. and F. H. Wang, 2009," Perverse Incentives at the Banks? - Evidence from a Natural Experiment", mimeo, Federal Reserve Bank of Chicago.

Berger, A. and G. Udell, 2004, "The Institutional Memory Hypothesis and the Procyclicality of Bank Lending Behavior," Journal of Financial Intermediation 13, 458-95.

Bernheim, B. D. and M. D. Whinston, 1986, "Menu Auctions, Resource Allocation, and Economic Influence," Quarterly Journal of Economics 101(1), 1-31.

Bertrand, M., F. Kramarz, A. Schoar, and D. Thesmar, 2004, "Politically Connected CEOs and Corporate Outcomes: Evidence from France," mimeo, University of Chicago.

Bolton, P., J. Scheinkman, and W. Xiong, 2006, "Executive Compensation and Short-termist Behaviour in Speculative Markets", Review of Economic Studies 73, 577-610.

Bostic R., K. Engel, P. McCoy, A. Pennington-Cross, and S. Wachter, 2008, "State and Local Anti-predatory Lending Laws: The Effect of Legal Enforcement Mechanisms", Journal of Economics and Business 60, 47-66.

Calomiris, C., 2009, “The Subprime Turmoil: What's Old, What's New, and What's Next”, Journal of Structured Finance 15 (1), 6-52.

Cheng, I.-H., H. Hong, and J. Scheinkman, 2010, “Yesterday's Heroes: Compensation and Creative Risk-Taking”, NBER WP No. 16176.

Claessens, S., E. Feijen, and L. Laeven, 2008, "Political Connections and Preferential Access to Finance: The Role of Campaign Contributions", Journal of Financial Economics 88 (3), 554-80.

Dell'Ariccia, G. and R. Marquez, 2006, "Lending Booms and Lending Standards", Journal of Finance 61 (5), $2511-46$.

Dell'Ariccia, G., D. Igan, and L. Laeven, 2008, “Credit Booms and Lending Standards: Evidence from the Subprime Mortgage Market”, CEPR Discussion Papers No. 6683. 
Diamond, D.W. and R. Rajan, 2009, “The Credit Crisis: Conjectures about Causes and Remedies", NBER Working Paper No. 14739.

Facchini, G., A. M. Mayda, and P. Mishra, 2008, "Do Interest Groups Affect Immigration Policy?”, CEPR Discussion Paper No. 6898, IMF WP No 08/244.

Faccio, M., 2006, "Politically Connected Firms", American Economic Review 96 (1), 369-86.

Faccio, M. and D. C. Parsley, 2007, "Sudden Deaths: Taking Stock of Geographic Ties", ECGI - Finance Working Paper No. 113/2006.

Fahlenbrach, R. and R. M. Stulz, 2009, “Bank CEO Incentives and the Credit Crisis”, NBER Working Paper 15212.

Fisman, R., 2001, "Estimating the Value of Political Connections", American Economic Review 91, 1095-102.

Fisman, D., R. Fisman, J. Galef, and R. Khurana, 2006, “The Cheney Effect: Valuing Political Connections in America", mimeo, Columbia University.

Gerardi, K., A. Lehnert, S. M. Sherland, and P. S. Willen, 2009, "Making Sense of the Subprime Crisis”, Public Policy Discussion Paper 09-1, Federal Reserve Bank of Boston.

Goldberg, P. K. and G. Maggi, 1999, “Protection for Sale: An Empirical Investigation”, American Economic Review 89 (5), 1135-55.

Gorton, G., 2008a, “The Panic of 2007," Proceedings of the 2008 Jackson Hole Conference, "Maintaining Stability in a Changing Financial System," Federal Reserve Bank of Kansas City.

Gorton, G., 2008b, “The Subprime Panic”, NBER Working Paper 14398.

Grossman, G. M. and E. Helpman, 1994, "Protection for Sale", American Economic Review 84, 833-50.

Grossman, G. and E. Helpman. 2001. Special Interest Politics. Cambridge, MA: The MIT Press.

Harstad, B. and J. Svensson, 2008, "From Corruption to Lobbying and Economic Growth", mimeo, Kellogg School of Management. 
Johnson, S., 2009, “The Quiet Coup,” The Atlantic, May; available at http://www.theatlantic.com/doc/200905/imf-advice.

Johnson, S. and T. Mitton, 2003, "Cronyism and Capital Controls: Evidence from Malaysia," Journal of Financial Economics 67, 351-382.

Khwaja, A. and A. Mian, 2005, "Do Lenders Favor Politically Connected Firms? Rent Provision in an Emerging Financial Market”, Quarterly Journal of Economics 120 (4).

Kiyotaki, N. and J. Moore, 1997, “Credit Cycles,” Journal of Political Economy 105, 211-48.

Kroszner, R. and P. Strahan, 1999, "What Drives Deregulation? Economics and Politics of the Relaxation of Bank Branching Restrictions", Quarterly Journal of Economics 114 (4), 1437-67.

Kroszner, R. and T. Stratmann, 1998, "Interest-Group Competition of Congress: Theory and Evidence from Financial Services’ Political Action Committees”, American Economic Review 88 (5), 1163-87.

Ludema, R., A. M. Mayda, and P. Mishra, 2010, "Protection for Free: An Analysis of U.S. Tariff Exemptions”, CEPR DP No. 7951, IMF Working Paper No. 10/211.

Mayer, C., K. Pence, and S. M. Sherlund, 2009, “The Rise in Mortgage Default", Journal of Economic Perspectives 23 (1), 27-50.

Mian, A. and A. Sufi, 2009, "The Consequences of Mortgage Credit Expansion: Evidence from the U.S. Mortgage Default Crisis", Quarterly Journal of Economics.

Mian, A., A. Sufi, and F. Trebbi, 2010a, "The Political Economy of the U.S. Mortgage Default Crisis," American Economic Review, December, 100(5): pp. 1967-98.

Mian, Atif, Amir Sufi, and Francesco Trebbi, 2010b, "The Political Economy of the Subprime Mortgage Credit Expansion”, NBER Working Paper No. 16107.

Potters, J. and F. Van Winden, 1992, “Lobbying and Asymmetric Information,” Public Choice 74, 269-92.

Stigler, G., 1971, “The Theory of Economic Regulation”, Bell Journal of Economics and Management Science, II, 3-21. 
Sirota, D., 2003, Essentials of Real Estate Finance, Dearborn Financial Publishing, Chicago.

Tressel, T. and T. Verdier, 2008, "Financial Globalization and the Governance of Financial Intermediaries", forthcoming, Journal of the European Economic Association. 
Figure 1. Evolution of lobbying Intensity (expenditures per firm) over

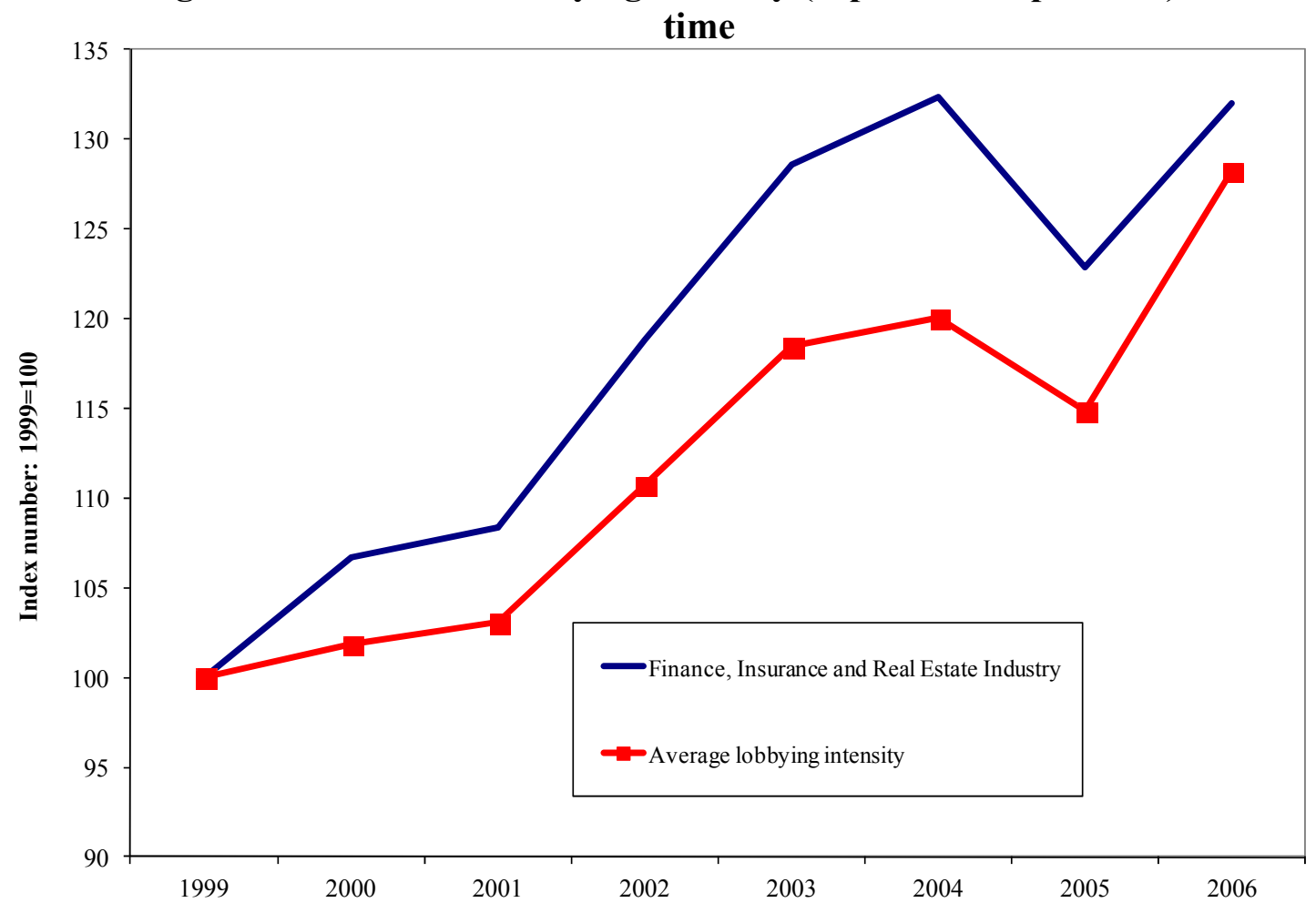


Figure 2. Lending Standards and Securitization

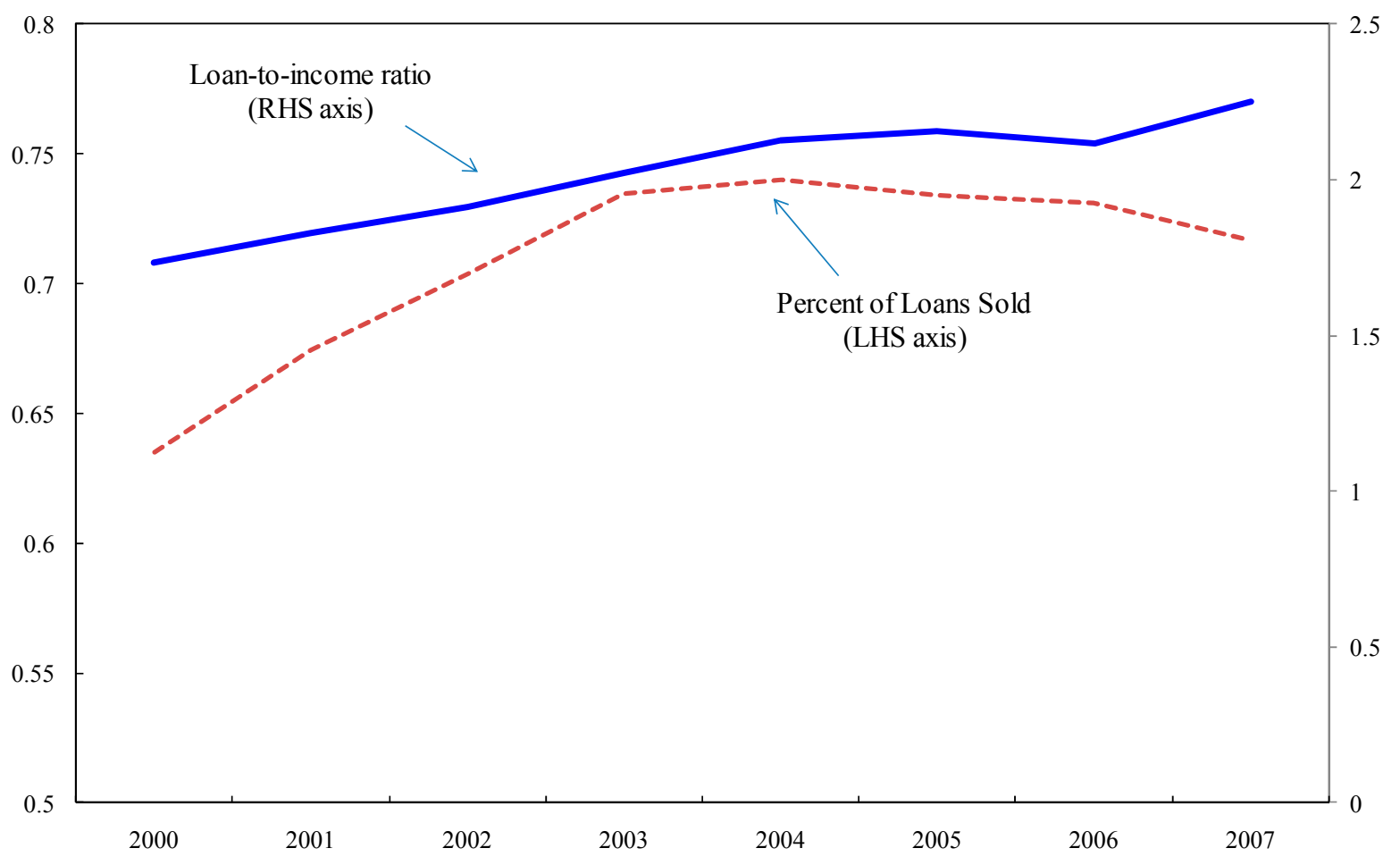




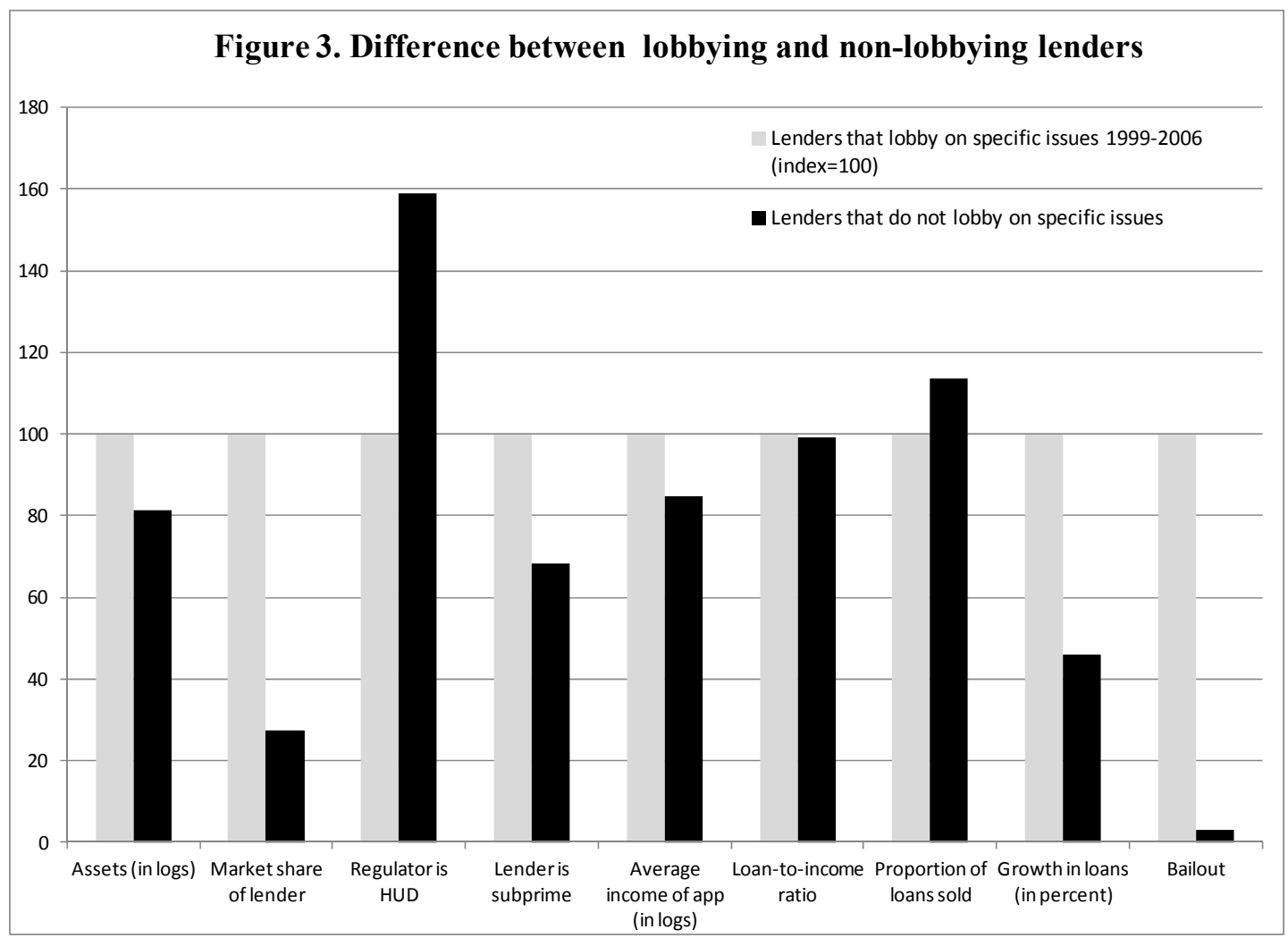


Table 1. Targeted Political Activity Campaign Contributions and Lobbying Expenditures (millions of dollars)

\begin{tabular}{lrrrr}
\hline Election cycle & & & & \\
Contributions from PACs & $1999-2000$ & $2001-02$ & $2003-04$ & $2005-06$ \\
Overall lobbying expenditure & 326 & 348 & 461 & 509 \\
$\quad 2,972$ & 3,348 & 4,081 & 4,747 \\
$\quad$ Of which expenditure by finance, insurance, & & & & \\
$\quad$ and real estate industry (FIRE) & 437 & 478 & 645 & 720 \\
$\quad$ Share of FIRE in overall lobbying (in percent) & 14.7 & 14.3 & 15.8 & 15.2 \\
Total targeted political activity & 3,298 & 3,696 & 4,542 & 5,256 \\
\end{tabular}

Source: Center for Responsive Politics. 
Table 2. Summary Statis tics

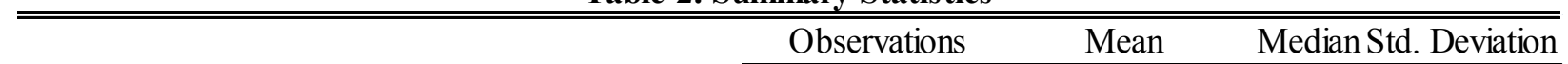

Lender-level variables

Lenders that lobby on specific issues

Loan-to-income ratio

Proportion of loans sold

Growth in amount of loans originated (in percent)

Market share of lender

Average income of loan applicants (in logs)

Assets (in logs)

Dummy $=1$ if regulator is HUD

Dummy $=1$ if lender is subprime

Lobbying expenditures on specific issues (in logs)

Lenders that do not lobby on specific issues

Loan-to-income ratio

Proportion of loans sold

Growth in amount of loans originated (in percent)

Market share of lender

Average income of loan applicants (in logs)

Assets (in logs)

Dummy $=1$ if regulator is HUD

Dummy $=1$ if lender is subprime

MSA-level variables

Average income (in '000)

GDP growth

Self-employment rate

Unemployment rate

Population (in logs)

House price appreciation

Number of competing lenders (in logs)

Number of loan applications (in logs)

Delinquency rate in 2008

Share of subprime loans in total loans

Share of hispanics in population

Share of college graduates in population

$\begin{array}{rrrr}73,374 & 2.02 & 1.98 & 0.70 \\ 73,374 & 0.63 & 0.80 & 0.38 \\ 56,504 & 3.80 & 0.12 & 143.63 \\ 73,374 & 0.01 & 0.00 & 0.03 \\ 73,374 & 7.65 & 7.49 & 2.38 \\ 73,374 & 14.65 & 16.76 & 4.31 \\ 73,374 & 0.37 & 0.00 & 0.48 \\ 73,374 & 0.30 & 0.00 & 0.46 \\ 73,374 & 6.68 & 9.96 & 5.37 \\ & & & \\ 575,564 & 2.00 & 1.93 & 0.95 \\ 575,564 & 0.71 & 1.00 & 0.41 \\ 371,875 & 1.75 & 0.07 & 38.13 \\ 575,564 & 0.00 & 0.00 & 0.01 \\ 575,564 & 6.47 & 6.18 & 2.01 \\ 575,564 & 11.89 & 10.34 & 3.31 \\ 575,564 & 0.59 & 1.00 & 0.49 \\ 575,564 & 0.21 & 0.00 & 0.41\end{array}$

\begin{tabular}{rrrr}
648,938 & 31.72 & 30.61 & 7.29 \\
648,938 & 0.05 & 0.05 & 0.03 \\
584,237 & 0.04 & 0.04 & 0.03 \\
648,084 & 0.05 & 0.05 & 0.02 \\
648,938 & 13.30 & 13.00 & 1.39 \\
646,366 & 0.07 & 0.05 & 0.07 \\
648,938 & 5.49 & 5.48 & 0.47 \\
648,938 & 9.91 & 9.78 & 1.30 \\
648,938 & 0.17 & 0.16 & 0.05 \\
648,938 & 0.10 & 0.09 & 0.04 \\
512,547 & 0.21 & 0.12 & 0.26 \\
512,547 & 0.23 & 0.22 & 0.07 \\
\hline
\end{tabular}


Table 3. Lobbying and Loan-to-Income Ratio

Dependent variable: Loan-to-income ratio at (lender, MSA, year) level

\begin{tabular}{|c|c|c|c|c|c|c|}
\hline & $\begin{array}{ll}\boldsymbol{7} & (1) \\
\end{array}$ & $(2)$ & $(3)$ & (4) & $(5)$ & $(6)$ \\
\hline Dummy $=1$ if lender lobbies on specific issues & $\begin{array}{c}0.016 * * * \\
{[0.005]}\end{array}$ & $\begin{array}{c}0.144 * * * \\
{[0.004]}\end{array}$ & $\begin{array}{c}0.075 * * * \\
{[0.004]}\end{array}$ & $\begin{array}{c}0.138 * * * \\
{[0.004]}\end{array}$ & $\begin{array}{c}0.145 * * * \\
{[0.004]}\end{array}$ & $\begin{array}{c}0.142 * * * \\
{[0.004]}\end{array}$ \\
\hline Dummy $=1$ if lender lobbies only on other issues & & & & & & $\begin{array}{c}-0.017 * * * \\
{[0.005]}\end{array}$ \\
\hline Number of observations & 648,938 & 581,105 & 648,938 & 581,105 & 648,938 & 648,938 \\
\hline R-squared & 0.00 & 0.10 & 0.14 & 0.16 & 0.18 & 0.18 \\
\hline MSA fixed effects & No & No & Yes & Yes & Yes & Yes \\
\hline Year fixed effects & No & No & Yes & Yes & Yes & Yes \\
\hline MSA*year fixed effects & No & No & No & No & Yes & Yes \\
\hline Additional controls & No & Yes & No & Yes & Yes & Yes \\
\hline
\end{tabular}

The regressions are run on the lender-MSA-year panel from 1999-2007. The dummy for lobbying on specific issues is equal to 1 if the lender lobbies for those issues in any year during 1999-2006. Lobbying on specific issues refers to lobbying on bills and regulations related to mortgage lending and securitization. Columns (2) and (4) include MSA-year-level controls for average income, GDP growth rate, selfemployment rate, unemployment rate, population, house price appreciation, number of competing lenders, and number of loan applications as well as lender-year-level controls for assets and dummies for HUD regulation and subprime, and MSA-lender-year-level controls for market share of lender and average income of loan applicants (calculated for each lender separately in each MSA using the loan applications and originations by the lender in a particular MSA in a given year). Columns (5) and (6) include only the MSA-lender-yearlevel and lender-year-level controls. Standard errors denoted in parentheses are clustered at the lender-MSA level. ***, ** and * represent statistical significance at 1,5 and 10 percent, respectively. 
Table 4. Lobbying Expenditures and Loan-to-Income Ratio

Dependent variable: Loan-to-income ratio at (lender, MSA, year) level

\begin{tabular}{|c|c|c|c|c|c|}
\hline & (1) & $(2)$ & $(3)$ & $(4)$ & (5) \\
\hline Lobbying expenditures on specific issues (in logs), lagged & $\begin{array}{c}0.007 * * * \\
{[0.000]}\end{array}$ & $\begin{array}{c}0.009 * * * \\
{[0.000]}\end{array}$ & $\begin{array}{c}0.003 * * * \\
{[0.001]}\end{array}$ & $\begin{array}{c}0.003 * * * \\
{[0.001]}\end{array}$ & $\begin{array}{c}0.002 * * * \\
{[0.001]}\end{array}$ \\
\hline Assets (in logs) & & & & & $\begin{array}{c}0.006^{* * *} \\
{[0.000]}\end{array}$ \\
\hline Market share of lender & & & & & $\begin{array}{c}3.017 * * * \\
{[0.090]}\end{array}$ \\
\hline Average income of loan applicants (in logs) & & & & & $\begin{array}{c}-0.031 * * * \\
{[0.001]}\end{array}$ \\
\hline Number of observations & 406,035 & 406,035 & 406,035 & 406,035 & 406,035 \\
\hline R-squared & 0.00 & 0.17 & 0.10 & 0.12 & 0.12 \\
\hline MSA fixed effects & No & Yes & Yes & Yes & Yes \\
\hline Year fixed effects & No & Yes & Yes & Yes & Yes \\
\hline Lender fixed effects & No & No & Yes & Yes & Yes \\
\hline MSA*year fixed effects & No & No & No & Yes & Yes \\
\hline
\end{tabular}

The regressions are run on the lender-MSA-year panel from 2000-07. Lobbying on specific issues refers to lobbying on bills and regulations related to mortgage lending and securitization. Assets vary at the lender-year level only. Market share of lender and average income of loan applicants are calculated for each lender separately in each MSA using the loan applications and originations by the lender in a particular MSA in a given year. Standard errors denoted in parentheses are clustered at the lender-MSA level. ***,** and

* represent statistical significance at 1, 5 and 10 percent, respectively. 
Table 5. Lobbying and Loan-to-Income Ratio: Difference-in-Difference

Dependent variable: Loan-to-income ratio at (lender, MSA, year) level

\begin{tabular}{|c|c|c|c|c|}
\hline & (1) & $(2)$ & $(3)$ & (4) \\
\hline Dummy $=1$ if anti-predatory lending law in (MSA, year) & $\begin{array}{c}0.166^{* * *} \\
{[0.004]}\end{array}$ & $\begin{array}{c}0.015 * * * \\
{[0.005]}\end{array}$ & $\begin{array}{c}0.006 \\
{[0.005]}\end{array}$ & $\begin{array}{c}0.006 \\
{[0.005]}\end{array}$ \\
\hline Lobbying expenditures on specific iss ues (in logs), lagged & $\begin{array}{c}0.007 * * * \\
{[0.001]}\end{array}$ & $\begin{array}{c}0.009 * * * \\
{[0.001]}\end{array}$ & $\begin{array}{c}0.008 * * * \\
{[0.001]}\end{array}$ & $\begin{array}{c}0.007 * * * \\
{[0.001]}\end{array}$ \\
\hline Lobbying expenditures on specific iss ues (in logs), lagged*Lending law & $\begin{array}{c}-0.001 \\
{[0.001]}\end{array}$ & $\begin{array}{c}-0.007 * * * \\
{[0.002]}\end{array}$ & $\begin{array}{c}-0.006 * * * \\
{[0.002]}\end{array}$ & $\begin{array}{c}-0.005 * * * \\
{[0.001]}\end{array}$ \\
\hline Number of observations & 406,035 & 406,035 & 355,656 & 355,656 \\
\hline R-squared & 0.01 & 0.10 & 0.10 & 0.10 \\
\hline Lender fixed effects & No & No & Yes & Yes \\
\hline MSA fixed effects & No & Yes & Yes & Yes \\
\hline Year fixed effects & No & Yes & Yes & Yes \\
\hline Additional controls & No & No & Yes & Yes \\
\hline
\end{tabular}

The regressions are run on the lender-MSA-year panel from 2000-07. Information on the enactment of state-level anti-predatory lending laws is from Bostic et al (2008). Lobbying on specific issues refers to lobbying on bills and regulations related to mortgage lending and securitization. Columns (3) includes MSA-year-level controls for average income, GDP growth rate, self-employment rate, unemployment rate, population, house price appreciation, number of competing lenders, and number of loan applications. Column (4), in addition to these MSA-year-level controls, includes lender-year-level controls for assets and MSA-lender-year-level controls for market share of lender and average income of loan applicants (calculated for each lender separately in each MSA using the loan applications and originations by the lender in a particular MSA in a given year). Standard errors denoted in parentheses are clustered at the lender-MSA level. ***, ** and * represent statistical significance at 1,5 and 10 percent, respectively. 
Table 6. Lobbying Expenditures, Proportion of Loans Sold, and Credit Growth

Dependent variable: Alternative measures for loan-to-income ratio

\begin{tabular}{|c|c|c|c|c|}
\hline \multirow[t]{2}{*}{ Dependent variable at (lender, MSA, year) level $\rightarrow$} & \multicolumn{2}{|c|}{ Proportion of loans sold } & \multicolumn{2}{|c|}{ Credit growth } \\
\hline & $(1)$ & (2) & (3) & (4) \\
\hline Lobbying expenditures on specific issues (in logs), lagged & $\begin{array}{c}0.007 * * * \\
{[0.000]}\end{array}$ & $\begin{array}{c}0.007 * * * \\
{[0.000]}\end{array}$ & $\begin{array}{c}0.318 * * \\
{[0.130]}\end{array}$ & $\begin{array}{c}0.321 * * * \\
{[0.118]}\end{array}$ \\
\hline Assets (in logs) & & $\begin{array}{c}-0.000 * * \\
{[0.000]}\end{array}$ & & $\begin{array}{c}-0.113 * * \\
{[0.047]}\end{array}$ \\
\hline Market share of lender & & $\begin{array}{c}0.216^{* * *} \\
{[0.026]}\end{array}$ & & $\begin{array}{c}-27.736 * * \\
{[12.114]}\end{array}$ \\
\hline Average income of loan applicants (in logs) & & $\begin{array}{c}0.002 * * * \\
{[0.000]}\end{array}$ & & $\begin{array}{c}0.740 * * * \\
{[0.079]}\end{array}$ \\
\hline Number of observations & 406,035 & 406,035 & 406,996 & 385,701 \\
\hline R-squared & 0.01 & 0.01 & 0.00 & 0.00 \\
\hline MSA fixed effects & Yes & Yes & Yes & Yes \\
\hline Year fixed effects & Yes & Yes & Yes & Yes \\
\hline Lender fixed effects & Yes & Yes & Yes & Yes \\
\hline MSA*year fixed effects & Yes & Yes & Yes & Yes \\
\hline
\end{tabular}

The regressions are run on the lender-MSA-year panel from 2000-07. Lobbying on specific issues refers to lobbying on bills and regulations related to mortgage lending and securitization. Assets vary at the lender-year level. Market share of lender and average income of loan applicants are calculated for each lender separately in each MSA using the loan applications and originations by the lender in a particular MSA in a given year. Standard errors denoted in parentheses are clustered at the lender-MSA level. ***, ** and $*$ represent statistical significance at 1,5 and 10 percent, respectively. 
Table 7. Lending by Lobbying Lenders and Delinquency Rates

Dependent variable: Delinquency rate in 2008 at MSA level

\begin{tabular}{|c|c|c|c|c|c|}
\hline & $(1)$ & $(2)$ & (3) & (4) & $(5)$ \\
\hline & & $\begin{array}{c}\text { excl. CA, } \\
\text { FL, NV \& } \\
\text { AZ }\end{array}$ & & IV:2SLS & IV: LIML \\
\hline $\begin{array}{l}\text { Growth in market share of lenders lobbying on specific issues } \\
\text { (average 2000-06) }\end{array}$ & $\begin{array}{l}0.718 * * * \\
{[0.152]}\end{array}$ & $\begin{array}{c}0.662 * * * \\
{[0.147]}\end{array}$ & $\begin{array}{c}0.734 * * * \\
{[0.158]}\end{array}$ & $\begin{array}{c}2.052 * * \\
{[0.816]}\end{array}$ & $\begin{array}{c}2.064 * * \\
{[0.825]}\end{array}$ \\
\hline $\begin{array}{l}\text { Growth in market share of lenders lobbying on other issues } \\
\text { (average 2000-06) }\end{array}$ & & & $\begin{array}{l}-0.022 \\
{[0.059]}\end{array}$ & & \\
\hline F-test of excluded instruments & & & & 9.63 & 9.63 \\
\hline Observations & 305 & 253 & 305 & 305 & 305 \\
\hline R-squared & 0.53 & 0.61 & 0.53 & 0.34 & 0.33 \\
\hline Hansen's J stat ( $p$ value) & & & & 0.744 & 0.745 \\
\hline
\end{tabular}

The regressions are run on the MSA cross-section. Lobbying on specific issues refers to lobbying on bills and regulations related to mortgage lending and securitization. All regressions include controls for average income, GDP growth rate, self-employment rate, unemployment rate, population, number of competing lenders, number of loan applications, share of subprime loans, share of hispanics, and share of college graduates are averages over 2000-06 for each MSA. House price appreciation is the cumulative change in house prices from 2000 to 2006. In columns (4) and (5), growth in market share of lenders lobbying on specific issues is instrumented by the initial market share of lenders lobbying on specific issues weighted by the distance of headquarters to DC (in logs) and the initial market share of lenders lobbying on unrelated issues weighted by the distance of headquarters to DC (in logs). ***,** and * represent statistical significance at 1, 5 and 10 percent, respectively. Robust standard errors are in brackets. 
Table 8. Lobbying and Abnormal Stock Returns

Dependent variable: Market- and risk-adjusted return at lender level

\begin{tabular}{lccc}
\hline \hline & $\begin{array}{c}(1) \\
\text { Bear Stearns } \\
\text { and Lehman } \\
\text { failures }\end{array}$ & & $(3)$ \\
Market Event & Lehman failure & $\begin{array}{c}\text { Bailout } \\
\text { announcement }\end{array}$ \\
\hline Dummy=1 if lender lobbies on specific issues & $\mathbf{- 0 . 2 0 7 * *}$ & $\mathbf{- 0 . 3 6 5 * *}$ & $\mathbf{0 . 3 0 1 * * *}$ \\
Dummy=1 if regulator is HUD & {$[\mathbf{0 . 0 9 0 ]}$} & $\mathbf{[ 0 . 1 7 5 ]}$ & {$[\mathbf{0 . 1 0 6}]$} \\
Dummy=1 if lender is subprime & -0.044 & -0.091 & -0.18 \\
& {$[0.106]$} & {$[0.204]$} & {$[0.143]$} \\
Assets (in logs) & $0.210^{* *}$ & $0.373 * *$ & -0.105 \\
& {$[0.096]$} & {$[0.185]$} & {$[0.122]$} \\
Mortgage loans originated / assets & -0.017 & -0.033 & 0.018 \\
& {$[0.014]$} & {$[0.026]$} & {$[0.018]$} \\
Number of observations & 0.0000 & -0.0001 & $-0.0003 * *$ \\
R-squared & {$[0.000]$} & {$[0.000]$} & {$[0.000]$} \\
\hline
\end{tabular}

Market- and risk-adjusted return is the stock price return over the month of the event, adjusted for the predicted return based on a CAPM where the market portfolio is proxied by the stock price index of financial institutions in the S\&P500. Market events around which market- and risk-adjusted returns are analyzed are (1) March 11-16, 2008: JP Morgan acquired Bear Stearns after Fed provided \$30 billion in non-recourse funding), (2) September 15-16, 2008: Lehman Brothers filed for bankruptcy and the authorities stepped in to rescue AIG), and (3) October 14, 2008: Troubled Asset Relief Program (TARP) making $\$ 700$ billion available for asset purchases was announced. The dummy for lobbying on specific issues is equal to 1 if the lender lobbies for those issues in any year during 1999-2006. Lobbying on specific issues refers to lobbying on bills and regulations related to mortgage lending and securitization. The HUD and subprime dummies are equal to one if the lender was HUD regulated or subprime respectively in any year during 1999-2007. Assets and mortgage loans to assets are for the year 2006. Event fixed effects are included in column (1). ${ }^{* *}, * *$ and * represent statistical significance at 1,5 and 10 percent, respectively. Robust standard errors are in brackets. 
Table 9. Lobbying and Bailout

Dependent variable: Bailout probability / amount at lender level

Dependent variable at (lender) level $\rightarrow$

\section{Dummy $=1$ if lender lobbies on specific issues}

\section{Lobbying expenditures on specific issues (in logs), total over 2000-06}

Assets (in logs)

Dummy $=1$ if regulator is HUD

Dummy $=1$ if lender is subprime

Market share of lender

Average income of loan applicants (in logs)

Loan-to-income ratio (averaged over 1999-2006)

Observations

R-squared

0.03

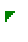

Dummy $=1$ if the lender got funds under TARP

(1)

$0.073 * * *$

[0.018]$$
r
$$

(2)

$0.069 * * *$

[0.018]

$018]$

$r$

$(3)$
$1.683^{* * *}$
$[0.404]$

TAR

(4)

$1.582 * * *$

[0.405]

[0.010]

$0.033^{* * *}$

[0.007]

\section{$0.001 * * *$}

[0.000]

$0.003^{* *}$

[0.001]

$0.062 * *$

$-0.003$

[0.004]

[0.030]

$-0.083$

[0.084]

0.079 *

[0.042]

$1.695 *$

[0.925]

0.007

0.000
$[0.000]$

[0.010]

0.022

0.001

[0.001]

13,315

13,172

0.03

[0.025]

13,172

13,315

0.03

$(5)$ by lender (in logs)

The regressions are run on the lender cross-section. The dummy for lobbying on specific issues is equal to 1 if the lender lobbies for those issues in any year during $1999-2006$. Lobbying on specific issues refers to lobbying on bills and regulations related to mortgage lending and securitization. In columns (1) and (2), the dependent variable is 1 if the lender or any of its affiliates were granted funds under the

Troubled Asset Relief Program (TARP) and 0 otherwise. In columns (3) to (6), the dependent variable is the amount, in logs, of funds received by the lender under TARP. Large lenders are defined by the top quartile of lobbying lenders (in terms of assets). Columns (2), (4), and (6) include lender-level controls for assets and dummies for HUD regulation and subprime and market share of lender and average income of loan applicants (calculated for each lender separately in each MSA using the loan applications and originations by the lender in a particular MSA and then averaged across MSAs and years).

Loan-to-income ratio, averaged for each lender across MSAs and over the years from 1999 to 2006, is also introduced as a right-hand-side variable to control for the riskiness of the mortgage loan portfolio over this period. Robust standard errors are in brackets. $* * *, * *$ and * represent statistical significance at 1,5 and 10 percent, respectively. 


\section{Appendix not for Publication}

\section{Home Mortgage Disclosure Act (HMDA)}

Enacted by Congress in 1975, the original purpose of the Act was two-fold: enhance enforcement of anti-discriminatory lending laws and disseminate information to guide investments in housing. The Act requires financial institutions to disclose information to their regulatory agency about every loan application received. Whether an institution is covered depends on its size, the extent of its activity in a metropolitan statistical area (MSA), and the weight of residential mortgage lending in its portfolio. Any depository institution with a home office or branch in an MSA must report HMDA data if it has made a home purchase loan on a one-to-four unit dwelling or has refinanced a home purchase loan and if it has assets above an annually adjusted threshold. Any non-depository institution with at least ten percent of its loan portfolio composed of home purchase loans must also report HMDA data if it has assets exceeding \$10 million. Under these criteria, small lenders and lenders with offices only in non-metropolitan areas are exempt from HMDA data reporting requirements. Therefore, information for rural areas tends to be incomplete. Yet, U.S. Census figures show that about 83 percent of the population lived in metropolitan areas over our sample period, and hence, the bulk of residential mortgage lending activity is likely to be reported under the HMDA. Information covers individual characteristics (race, ethnicity, income, geographic location of the property, etc.), loan information (amount requested, response, reasons for denial, etc.) and institution information (regulatory authority, geographic location, and assets). The data can be ordered on CD-ROM's from the Federal Financial Institutions Examination Council (FFIEC), and starting in 2006 they can also be downloaded from their website. The data cover about 250 million loan applications between 1996 and 2007.

In order to make sure that the data are clear of outliers and erroneous values, we follow these procedures:

- Loan amount and applicant income are rounded to a lower limit, hence all observations below $\$ 1000$ and $\$ 10000$, respectively, are eliminated.

- Definitions of applicant race, loan purpose and purchaser type have changed between 2003 and 2004. For applicant race, an applicant ethnicity variable has been added and the race code for Hispanic has been eliminated. Other codes have been rearranged. In our dataset, these variables are transformed into harmonized dummies for selected ethnicities. Loan purpose category "multifamily" has been moved to a new specific variable called property type in 2004. In order to harmonize the pre-2003 and post-2003 data, all multifamily-related records are eliminated. Purchaser type has gone under a minor recoding to make room for "securitization", i.e. the packaging and sale of loans on the open market, as opposed to the sale of the whole loan to a private institution or governmentsponsored enterprise. As we do not distinguish between loan sales and securitized loans, no adjustments are made for this change. 
- We eliminate all application records that did not end in one of the three following actions: loan originated, application approved but not accepted, application denied. Other actions mostly represent dubious statuses (e.g. application withdrawn by applicant) or purchased loans; these have also been excluded because it is not clear whether they are reported twice, once by the originating institution and again by the purchasing institution.

Although HMDA is a relatively homogeneous dataset considering its size, there are some inconsistencies that need to be dealt with. First, HMDA disclosure requirements change, although minimally, from one year to the next to reflect changes in metropolitan area definitions and keep minimum institution size in line with inflation. While there is little that can be done to take account of the fact that the set of institutions qualifying under the applicable rules on the size restriction change, we eliminate the observations that cannot be associated with a metropolitan area, which typically turn out to be loans made in rural areas by institutions whose primary business is in metropolitan areas and are therefore required to report or loans that were made in an area that happened to be reclassified as rural. Second, 2004 was marked by a major overhaul of the HMDA regulations. New variables were added, including the interest rate when it is set above a certain threshold: the number of variables expanded from 30 to 45. Moreover, the Office of Management and Budget (OMB) increased the number of official Metropolitan areas (MAs) from about 320 to about 390. The boundaries of the MAs themselves were sometimes enlarged, increasing the number of lenders required to report. Trends apparent from a comparison of aggregate figures from 2003 and 2004, therefore, should be taken with a grain of salt. For example, loan market growth rates are likely to be inflated because in the existing MAs more institutions were required to disclose; at the same time, in a specific MA figures could be understated because part of the counties that used to form it have been incorporated into a new MA. In such cases, 2004 aggregate figures have been interpolated using 2003 and 2005 figures. Third, some Loan Application Records (LARs) were found to be wrong or inconsistent by numerous data validity checks operated by the FFIEC. Such records, after being altered automatically, have been marked as "edited" using a flag. Around 6 percent of all records are marked as edited. Edits are distributed in a homogeneous fashion across time and across space. In any event, those records have been eliminated from our database. ${ }^{1}$

To concentrate on a relatively homogeneous set of loans, we drop loans for multi-family purpose from the sample, as this is a distinct market from the overall mortgage market for single family homes. We also drop federally insured loans as their risk profile is likely to differ from that of other loans.

HMDA data does not include a field that identifies whether an individual loan application is a subprime loan application. In order to distinguish between the subprime and prime loans, we use the subprime lenders list as compiled by the U.S. Department of Housing and Urban

\footnotetext{
${ }^{1}$ An exception is Arizona in 2003. For most Arizona MAs in 2003 nearly all records are reported as edited. While the reasons of this remain unknown, such records have been eliminated, and 2003-04 credit growth rates have been interpolated using data from the adjacent years.
} 
Development (HUD) each year. HUD has annually identified a list of lenders who specialize in either subprime or manufactured home lending since 1993. HUD uses a number of HMDA indicators, such as origination rates, share of refinance loans, and proportion of loans sold to government-sponsored housing enterprises, to identify potential subprime lenders. Since 2004, lenders are required to identify loans for manufactured housing and loans in which the annual percentage rate (APR) on the loan exceeds the rate on the Treasury security of comparable maturity by at least three (five, for second-lien loans) percentage points and report this information under HMDA. The rate spread can be used as an alternative indicator (to the HUD list) to classify subprime loans. For the years with available data, the ranking of subprime lenders using the rate spread variable alone coincides closely with the ranking in the HUD list (the correlation is around 0.8).

\section{Data at the Metropolitan Statistical Area (MSA) Level}

Despite its broad coverage on borrower, property, and loan characteristics, several important variables that might have an impact on lending decisions are left out in HMDA. The lack of knowledge on the applicant's credit score and age, interest rate and maturity of the loan, and property price are just examples of missing fundamental information on which the lender might base the decision. Some of this essential information might be partially recovered through use of economic and social indicators available for the geographical area. For that purpose, we gather data from the following sources.

- Bureau of Economic Analysis (BEA): Annual data on personal income, labor and capital remuneration, proprietors' employment, and population.

- Bureau of Labor Statistics (BLS): Data on unemployment and prices

- U.S. Census Bureau: Data on population

- Office of Federal Housing Enterprise Oversight (OFHEO): Housing price index (HPI)

- LoanPerformance: Mortgage delinquencies (percent of subprime loans that are 60 or more days delayed in payment) from LoanPerformance at four different points in time (February 2005, 2006 and 2007 and November 2007).

\section{Adjustment for Change in Metropolitan Area Definitions}

The definitions of MAs change over time, both because of change in administrative standards and, more often, because of the dynamic nature of cities. OMB operated a major change in the definitions in 2003, and HMDA incorporated this change into its requirements in 2004. Hence, it is necessary to adjust the aggregation of data to reflect these changes in definitions to make sure that data are consistent pre- and post-2004. Further harmonization of metropolitan area definitions is necessary as some sources use different codes.

The new codes identify physical MAs as Core-Based Statistical Areas (CBSAs). A CBSA can span more than one state but always covers counties in their entirety without splitting them. Large areas such as New York-Newark-Bridgeport (NY-NJ-CT-PA) are in turn 
subdivided into Metropolitan Divisions (MDs) in order to maintain a more comparable area size. MDs, too, are made up of whole counties. The only exception to this rule is the New England City and Town Areas (NECTAs) used by BLS. Due to historical reasons, New England city boundaries are administratively allowed to cut across counties. It is therefore impossible to match NECTA borders to CBSA and MD codes; while there are CBSA codes for Boston and other NECTAs, the Census Bureau warns that these codes represent statistical artifacts that do not match exactly the actual borders. For this reason, unemployment and inflation figures for NECTAs have been imputed without adjustment to the corresponding CBSAs (hence, at the highest level of aggregation to minimize errors). LoanPerformance data, excluding the November 2007 version, are expressed using the 1999 codes. At a first approximation, in the 1999 codebook CBSAs were replaced by Consolidated Metropolitan Statistical Areas (CMSAs) and MDs were replaced by Primary Metropolitan Statistical Areas (PMSAs). In order to fit PMSA-based data to our dataset, the data were merged to single counties according to their former PMSA; CBSA values were then calculated by averaging the value taken by each of the counties constituting the CBSA. This way it was possible to have a continuous and consistent series where one PMSA has been split into two CBSAs in the new codes, or vice versa. However, some of the seventy new MAs of the 2003 definition are new areas, that only recently reached the metropolitan area threshold, and therefore these areas have been excluded.

HMDA data always report the county where the property is located, and therefore it was possible to associate the 2003 definitions with pre-2004 data. We recreate two artificial, coherent "CBSA" and "MD" variables for the individual data in all seven years. Of course, the pre-2004 coverage of MAs created in 2004 is not complete, as local institutions were deemed to be rural and therefore not required to file under HMDA. On the other hand, a large part of lending in non-metropolitan cities is still carried out by lenders that are required to file so we include these observations.

\section{Lobbying Expenditures}

In addition to campaign contributions to officials and candidates for election purposes, companies, labor unions, and other organizations spend billions of dollars each year to lobby incumbent members of Congress and of federal agencies. Some special interests hire lobbying firms; others have lobbyists working in-house. We compile the dataset on lobbying expenditures using two sources: (i) the website of the Center for Responsive Politics (CRP) (www.crp.org) and (ii) website of the Senate's Office of Public Records (SOPR) -http://www.senate.gov/legislative/Public_Disclosure/LDA_reports.htm. The data are based on the semi-annual lobbying disclosure reports filed with the SOPR and posted to their website. We focus on the reports covering lobbying activity that took place from 1999 through 2006.

The website of the CRP provides information on the lobbying expenditures as well as the general issues with which lobbying is associated. The information however, is not userfriendly (e.g. one has to click on each firm name to get the details), and often has to be crosschecked with individual lobbying reports which are publicly available in pdf format on the website of the SOPR. Moreover, the CRP does not provide information on the specific 
issues (or particular regulations) with which the lobbying is associated. We extract the entire lobbying database from the CRP website (comprising about 16,000 unique firms over 19992006, with a maximum of around 9,000 firms in any one year) and use it for the matching process with HMDA database. For the matched firms (around 250), we go over the individual pdf reports to extract detailed information including specific issues.

The Lobbying Disclosure Act (LDA) of 1995 requires lobbying firms and organizations to register and file reports of their lobbying activities with the Secretary of the Senate and the Clerk of the House of Representatives. In general, it requires registration by any individual lobbyist (or the individual's employer if it employs one or more lobbyists) within 45 days after the individual first makes, or is employed or retained to make, a lobbying contact with either the President, the Vice President, a Member of Congress, or any other specified Federal officer or employee, including certain high-ranking members of the uniformed services.

A registrant must file a report for the semiannual period when registration initially occurred and for each semiannual period thereafter, including the period during which registration terminates. Lobbying firms, i.e., entities with one or more lobbyists, including self-employed individuals who act as lobbyists for outside clients, are required to file a separate report for each client covered by a registration. Organizations employing in-house lobbyists file a single report for each semiannual period. The semiannual report is required to be filed no later than 45 days after the end of a semiannual period beginning on the first day of January and the first day of July of every year in which a registrant is registered. LDA requires the Secretary of the Senate and the Clerk of the House of Representatives to make all registrations and reports available to the public as soon as practicable after they are received.

Under Section 3(10) of the LDA, an individual is defined as a "lobbyist" with respect to a particular client if he or she makes more than one lobbying contact (i.e. more than one communication to a covered official) and his or her "lobbying activities" constitute at least 20 percent of the individual's time in services for that client over any six-month period. "Lobbying activity" is defined in Section 3(7) of the LDA as "lobbying contacts or efforts in support of such contacts, including background work that is intended, at the time it was performed, for use in contacts, and coordination with the lobbying activities of others".

Lobbying firms are required to provide a good-faith estimate rounded to the nearest $\$ 20,000$ of all lobbying-related income in each six-month period. Likewise, organizations that hire lobbyists must provide a good-faith estimate rounded to the nearest $\$ 20,000$ of all lobbyingrelated expenditures in a six-month period. An organization or a lobbying firm that spends less than $\$ 10,000$ in any six-month period does not have to state its expenditures. In those cases, CRP treats the figure as zero.

Annual lobbying expenditures and incomes (of lobbying firms) are calculated by adding midyear totals and year-end totals. Whenever a lobbying report is amended, income/expense figures from the amendment are generally used instead of those from the original filing. Often, however, CRP staff determines that the income/expenditures on the amendment or termination report are inaccurate. In those instances, figures from the original filing are used. 
Occasionally, income that an outside lobbying firm reports receiving from a client is greater than the client's reported lobbying expenditures. Many such discrepancies can be explained due to filer error. In cases not already resolved in previous reports and where the discrepancy exceeds the $\$ 20,000$ that can be attributed to rounding, the client's expenditures rather than the lobbying firm's reported income are used. The only exception is when a client reports no lobbying expenditures, while the outside lobbying firm lists an actual payment. In such cases, the figure reported by the lobbying firm is used.

In cases where the data appears to contain errors, official Senate records are consulted and, when necessary, the CRP contacts SOPR or the lobbying organizations for clarification. The CRP standardizes variations in names of individuals and organizations to clearly identify them and more accurately represent their total lobbying expenditures.

In cases where both a parent and its subsidiary organizations lobby or hire lobbyists, the CRP attributes lobbying spending to the parent organization. Therefore, the lobbying totals reported by the CRP for a parent organization may not reflect its original filing with the Senate, but rather the combined expenditures of all related entities.

However, to calculate lobbying expenditures by sector and industry, each subsidiary is counted within its own sector and industry, not those of its parent. The CRP makes this distinction when it has the information necessary to distinguish some or all of the subsidiary's lobbying expenditures from either the subsidiary's own filing or from the receipts reported by outside lobbying firms. For example, tobacco giant Altria Group owns Kraft Foods. Although Altria Group's original filing includes lobbying for Kraft in its expenditures, in the dataset the CRP isolates Kraft's payments to outside lobbyists and includes them in 'Food Processing and Sales'.

When companies merge within any two-year election cycle, their lobbying expenditures are combined and attributed to the new entity. This is done in order to correlate lobbying data to campaign contribution data for each particular organization and industry.

In addition to firms' own lobbying expenditures, we also include lobbying expenditures by finance, insurance, real estate trade associations; that is, we are interested in associations such as the Electronic Check Clearing House Organization (ECCHO) or the Financial Services Roundtable. To split the total association expenditures among the various association members, we first obtain membership information from approximately 150 association websites. For example, according to the ECCHO website, there are more than 2200 members including Bank of America, Citibank, and SunTrust. Next, a share of the associations' lobbying expenditures is assigned to each member firm. This share is calculated as the member firm's own lobbying expenditures divided by the sum of all association members' lobbying expenditures. Then, for each firm and each year, the firm's share is multiplied by the association's total lobbying expenditures so that the association lobbying expenditures are distributed across all of the member firms.

Interestingly, the LDA also requires the organization to state the issues on which the registrant engaged in lobbying during the reporting period. Table A1 shows 76 issues, of 
which at least one has to be entered by the registrant/filer. The filer can list more than one issue. In that case, she has to use a separate page of the form for each code selected.

For each general issue, the filer is also required to list the specific issues which were lobbied for during the semi-annual period. For example, specific bills before Congress or specific executive branch actions are required to be listed in the form.

Table A2 shows a sample form filed by Bear Stearns for lobbying activity between July 1 December 31, 2007; Table A3 shows a sample form filed by Bank of America for lobbying activity between July 1 - December 31, 2006. Only three selected pages of each form are shown. Page 1 of the form shows the name and details of each company, the time period covered by the report and the expenses incurred by each company relating to lobbying activity during this period (for Bear Stearns, expenses were \$500,000, and for Bank of America, \$1,020,000). The lobbying expenditure is listed only once on the first page of the form and the amount is not split among the issues. The other two pages of the forms show general issues for which the companies engaged in lobbying activity (Bear Stearns: Banking and Bankruptcy; Bank of America: Banking and Housing).

\section{Specific House and Senate Bills of Interest}

We focus on five general lobbying issues: Accounting, Banking, Bankruptcy, Housing, and Financial Institutions. Moreover, certain House and Senate bills are of particular interest since they promote either tight or lax restrictions in these five general areas of interest.

Bills that introduce tight restrictions for lenders focus primarily on predatory lending practices $^{2}$ and high-cost mortgages ${ }^{3}$. For example, many bills contain restrictions/limits on annual percentage rates for mortgages, negative amortization, pre-payment penalties, balloon payments, late fees, and/or the financing of mortgage points and fees. Expanded consumer disclosure requirements regarding high-cost mortgages (such as including the total cost of

\footnotetext{
${ }^{2}$ While there is no single legal definition of predatory lending practices, the U.S. Department of Housing and Urban Development offers the following examples as predatory lending practices by creditors: 1) charging unnecessary fees; 2) lending more money than a borrower could repay; 3 ) encouraging borrowers to lie on credit applications; 4) changing the terms of the loan at closing; 5) signing blank loan paperwork; and 6) charging higher fees based on a consumer's race and not on a consumer's credit history. (Please see http://www.hud.gov/offices/hsg/sfh/buying/loanfraud.cfm for more information.) For additional information, please see the National Conference on State Legislatures' website (http://www.ncsl.org/programs/banking/predlend_intro.htm) for an overview of the predatory lending practices outlawed by each state legislature.

${ }^{3}$ High-cost mortgages are often defined as mortgages that have annual percentage rates (APRs) that exceed the APR on Treasury securities by a certain number of percentage points. For example, the Predatory Lending Consumer Protection Act of 2002 (S. 2438) amended the Home Ownership Equity Protection Act to define high cost first mortgages as either 1) mortgages with APRs that are six percentage points above the Treasury security APR or 2) mortgages where the total cost of points and fees is greater than five percent of the total loan amount or $\$ 1000$.
} 
lender fees on loan settlement paperwork or disclosing to consumers that they are borrowing at a higher interest rate) are introduced in some of the bills.

Many of the bills prohibit high-cost mortgage lenders from engaging in other unfair or deceptive practices. Creditors are to evaluate each consumer's ability to repay a loan before making the loan, and one bill stipulates that mortgage debt is not to exceed 50 percent of an individual's income, and income is to be verified. Creditors are not to encourage consumers to default on loans; moreover, mortgage lenders and other creditors must report their consumers' payment histories to credit reporting agencies. High-cost mortgage lenders may not accelerate a consumer's debt if the consumer is making payments on time. In addition, individuals who provide mortgage lending or brokerage services must be adequately trained in high-cost lending. Civil penalties for engaging in predatory lending practices are increased.

Some of the bills that firms and/or associations lobby for are closely related as it is common for various versions of the same bill to come in front of the House/Senate in the legislative process. To exploit any information that might be contained in the number of times a specific issue is discussed, we identify groups of bills that have the same name (or very similar names) and/or contain essentially the same language. For example, we consider the following bills to be a group: S. 2415: Predatory Lending Consumer Protection Act of 2000; H.R. 4250: Predatory Lending Consumer Protection Act of 2000; S. 2438: Predatory Lending Consumer Protection Act of 2002; H.R. 1051: Predatory Lending Consumer Protection Act of 2001. Once the related bills are grouped, we count the total number of times an individual bill or at least one of the bills in a group was listed as a specific issue of interest by either firms or associations. Based on these counts, we rank the "popularity" of the bills and groups of bills. The first 19 spots in the ranking are groups of bills, while S. 900 (the GrammLeach-Bliley Act) is the most common individual bill for which firms and/or associations lobby. We have one ranking for all of the bills and groups of bills; the other ranking is only for the top 100 most common bills or groups of bills. We use these counts and rankings as weights to split the total lobbying expenditure. Essentially, the firms' lobbying expenditure is multiplied by the count and the two rank variables to produce three scaled lobbying expenditure variables.

The following bulleted list offers greater detail on each of the specific bills that promote tighter restrictions in Accounting, Banking, Bankruptcy, Finance, and Housing:

\section{- H.R. 1051: Predatory Lending Consumer Protection Act of 2001}

○ Introduced March 15, 2001; Never passed by House or Senate; Never signed into law

○ H.R. 1051 amends the Truth in Lending Act regarding allowable annual percentage rates, total points and fees, pre-payment penalties, and balloon payments for high cost mortgages. The bill also requires additional disclosures to consumers and restricts high-cost mortgage creditors in financing mortgage points and fees and from accelerating a consumer's debt or from encouraging consumer default. Consumers must fulfill a credit counseling requirement. 
- H.R. 1163: Predatory Mortgage Lending Practices Reduction Act

○ Introduced April 8, 2003; Never passed by House or Senate; Never signed into law

- H.R. 1163 requires that any individual who provides mortgage lending or brokerage services be adequately trained in subprime lending. The bill also includes subprime lender requirements and prohibitions and penalties for unfair and deceptive practices. Furthermore, H.R. 1163 extends grants to community organizations offering education on subprime or illegal lending practices.

- H.R. 1182: Prohibit Predatory Lending Act 2005

○ Introduced March 9, 2005; Never passed by House or Senate; Never signed into law

○ H.R. 1182 defines high-cost mortgages as 1) any primary mortgage with an interest rate eight percentage points above the yield on Treasury securities or 2 ) any secondary mortgage with an interest rate ten percentage points above the yield on Treasury securities. The bill addresses the calculation of points and pre-payment penalties; furthermore, it contains restrictions on balloon payments and late fees and prohibits debt acceleration. Additionally, H.R. 1182 prevents lenders from extending to credit to individuals who do not have the ability to repay the debt. For example, mortgage debt is not to exceed 50 percent of an individual's income, and income is to be verified by pay stubs, tax returns, etc.

- H.R. 1295: Responsible Lending Act

○ Introduced March 15, 2005; Never passed by House or Senate; Never signed into law

○ H.R. 1295 defines "higher-cost mortgage" and includes requirements for mortgage product evaluation software and appraisals for properties secured by higher-cost mortgages. In addition, mortgage pamphlets distributed to consumers are to be updated and simplified and explain topics such as balloon payments, escrow accounts, and consumer responsibilities; furthermore, information should be provided in multiple languages and formats to reach vulnerable populations.

- H.R. 1865: Prevention of Predatory Lending Through Education Act

○ Introduced April 29, 2003; Never passed by House or Senate; Never signed into law

- Under H.R. 1865, the Secretary of Housing and Urban Development is to award grants to state and local governments and non-profit organizations so that they may counsel and educate consumers on predatory lending practices.

- H.R. 3607: Protecting Our Communities From Predatory Lending Practices Act

$\circ$ Introduced December 20, 2001; Never passed by House or Senate; Never signed into law 
○ H.R. 3607 prohibits unfair or deceptive practices and statements regarding consumer credit transactions, applications, etc. In addition, the bill includes provisions that prohibit certain practices involving a consumer's dwelling; that is, practices such as flipping consumer loans, financing credit insurance, charging fees for services not provided, and others are prohibited.

- H.R. 3807: Predatory Mortgage Lending Practices Reduction Act

○ Introduced February 27, 2002; Never passed by House or Senate; Never signed into law

○ Please see H.R. 1163.

\section{- H.R. 3901: Anti-Predatory Lending Act of 2000}

○ Introduced March 9, 2000; Never passed by House or Senate; Never signed into law

- H.R. 3901 adds the following disclosure requirement to the Home Mortgage Disclosure Act of 1975: "the annual percentage rate of mortgage loans and home improvement loans originated by the institution grouped according to census tract, income level, racial characteristics, and gender." The bill restricts certain rates and fees and mandates that any borrower who would like to obtain a high-cost mortgage complete home ownership counseling. Prepayment penalties, negative amortization, flipping home loans, extending credit without regard to ability to repay, encouraging default, payments to appraisers by creditors, and creditor-financing of credit insurance are disallowed.

\section{- H.R. 3915: Mortgage Reform and Anti-Predatory Lending Act of 2007}

- Introduced October 22, 2007; Passed by House November 15, 2007; Never passed by Senate; Never signed into law

$\circ$ H.R. 3915 introduces licensing and training requirements for individuals wishing to become loan originators. In addition, the bill stipulates that certain federal agencies are to regulate mortgage lenders so that they do not encourage borrowers from taking on loans that they do not have the ability to repay. Good faith estimates must include the total loan amount, the type and length of the loan, the annual percentage rate, the total estimated monthly payment, the percentage the monthly payment is of the borrower's monthly income, and other disclosures.

- H.R. 4213: Consumer Mortgage Protection Act of 2000

- Introduced April 6, 2000; Never passed by House or Senate; Never signed into law

- The Consumer Mortgage Protection Act of 2000 revises regulations on fees, points, closing costs, annual percentage rates, and pre-payment penalties. Creditors are not to encourage consumers to default on loans and must report quarterly to credit bureaus on the status of consumer loans.

\section{- H.R. 4250: Predatory Lending Consumer Protection Act of 2000}


- Introduced April 12, 2000; Never passed by House or Senate; Never signed into law

- H.R. 4250 requires additional disclosures to consumers who are applying for high-cost mortgages to warn them regarding the higher interest rates and the risks associated with high-cost mortgages. Pre-payment penalties, balloon payments, and the financing of points and fees are restricted. Creditors must evaluate each consumer's ability to repay the loan, and creditors must not encourage a consumer to default on the loan.

- H.R. 4471: Fair and Responsible Lending Act

- Introduced December 8, 2005; Never passed by House or Senate; Never signed into law

- H.R. 4471 regulates fees, payments, and other costs associated with high-cost home loans. The bill requires that a consumer considering a high-cost mortgage attend credit counseling services. Computer software programs designed to help consumers choose among mortgage products must be certified by the Secretary of Housing and Urban Development.

- H.R. 4818: Mortgage Loan Consumer Protection Act

- Introduced May 22, 2002; Never passed by House or Senate; Never signed into law

- H.R. 4818 requires disclosure of lenders' fees on settlement paperwork and prohibits lenders from charging certain loan fees.

- H.R 833: Responsible Lending Act

- Introduced February 13, 2003; Never passed by House or Senate; Never signed into law

- See also H.R. 1295. H.R. 833 defines high cost mortgages, points, and fees. The bill also creates the Consumer Mortgage Protection Board to offer grants to organizations providing homeownership/rental counseling. Mortgage broker guidelines and requirements are also included in the bill.

- S. 2415: Predatory Lending Consumer Protection Act of 2000

- Introduced April 12, 2000; Never passed by House or Senate; Never signed into law

- S. 2415 amends the Truth in Lending Act regarding annual percentage rates, total points and fees, pre-payment penalties, and balloon payments for high cost mortgages. The bill also requires additional consumer disclosures and restricts high-cost mortgage creditors from financing mortgage points and fees and from accelerating a consumer's debt or from encouraging consumer default. High-cost mortgage lenders must report their consumers' payment histories to credit reporting agencies. Civil penalties and the statute of limitations are increased.

\section{- S. 2438: Predatory Lending Consumer Protection Act of 2002}


- Introduced May 1, 2002; Never passed by House or Senate; Never signed into law

- S. 2438 amends the Truth in Lending Act regarding high cost mortgages; as such, the bill requires additional disclosures to the consumer, prohibits balloon payments and prepayment penalties, and limits the points/fees a lender may charge for high cost mortgages. Creditors must report a consumer's payment history/status to consumer reporting agencies.

\section{- H.R. 2201: Consumer Debt Prevention and Education Act of 2005}

$\circ$ Introduced May 5, 2005; Never signed into law

- H.R. 2201 excludes medically distressed individuals from means test requirements for Chapter 7 bankruptcy filings. The bill also requires any credit issuer mailing credit applications to consumers to include a brochure explaining how negative credit scores and being over the limit can affect a consumer credit status. The brochure must also include information on how long it will take to pay off a credit card balance if the consumer only makes minimum payments.

\section{- H.R. 3763: Sarbanes-Oxley Act of 2002}

- Introduced February 14, 2002; Passed House April 24, 2002; Passed Senate July 15, 2002; Signed into law July 30, 2002

- H.R. 3763 establishes the Public Company Accounting Oversight Board to oversee audit-related issues. The bill also addresses auditor independence and prevents any auditor from providing non-audit related services for the same company. Auditor rotation and reporting guidelines are included.

- Under H.R. 3763, the principal executive and financial officers are to certify the financial reports and forgo certain bonuses and compensation if certain violations of securities laws occur. The chief executive officer must sign the corporation's tax returns. Insider trading during certain blackout periods is disallowed. The bill also calls for increased financial disclosures and assigns corporate and criminal fraud liability and increases the penalties for whitecollar crimes.

\section{- H.R. 4541: Commodity Futures Modernization Act of 2000}

○ Introduced May 25, 2000; Passed House October 19, 2000; Never signed into law

- Under H.R. 4541, the following types of contracts and transactions are excluded from the Commodity Exchange Act: 1) foreign currency; 2) government securities; 3) security warrants; 4) security rights; 5) resales of installment loan contracts; 6) repurchase transactions in an excluded commodity; 7) mortgages or mortgage purchase commitments; 8) electronic trading of excluded commodities; 9) qualifying hybrid instruments; and 10) swap transactions.

- The bill revises registration requirements for security futures product exchanges and exempts certain floor brokers/traders from registration requirements. Rules and provisions for securities futures trading are included. 


\section{- S. 2697: Commodity Futures Modernization Act of 2000}

○ Introduced June 8, 2000; Never signed into law

○ See H.R. 4541

A second group of bills loosens restrictions for lenders in the general issues of Accounting, Banking, Bankruptcy, Finance, and Housing. For example, the bills related to housing use a wide array of tools including lower down-payment requirements; state and local grant funding to provide down-payment assistance for certain borrowers; hybrid adjustable rate mortgage programs; revised mortgage insurance premiums and cancellation policies; and financial assistance when purchasing homes in high-crime areas or low-income areas. Another channel through which these housing bills incorporate lax housing regulations is relaxing restrictions on Federal Housing Administration (FHA) loans and oversight of the Federal National Mortgage Association (Fannie Mae), the Federal Home Loan Mortgage Corporation (Freddie Mac), and the Federal Home Loan Banks.

The following bulleted list offers greater detail on each of the Accounting, Banking, Bankruptcy, Finance, and Housing bills that relax restrictions:

\section{- H.R. 1276: American Dream Downpayment Act}

- Introduced March 13, 2003; Passed by House October 1, 2003; Never passed by Senate; Never signed into law

- H.R. 1276 amends the Cranston-Gonzalez National Affordable Housing Act and offers down-payment assistance to certain low-income individuals, firsttime home buyers, uniformed employees, or teachers through the use of grants to state and local governments.

\section{- H.R. 1461: Federal Housing Finance Reform Act of 2005}

- Introduced April 5, 2005; Passed by House October 26, 2005; Never passed by Senate; Never signed into law

- The Federal Housing Finance Reform Act of 2005 creates the Federal Housing Finance Agency (FHFA) which would have oversight of Freddie Mac, Fannie Mae, and Federal Home Loan Banks. FHFA would become the single regulator for Freddie Mac and Fannie Mae; the Department of Housing and Urban Development would no longer have oversight. The bill requires Freddie Mac and Fannie Mae to set aside funds directed at increasing homeownership among low-income individuals or in low-income areas.

- H.R. 1629: FHA Multifamily Housing Mortgage Loan Limit Adjustment Act of 2001

- Introduced April 26, 2001; Never passed by House or Senate; Never signed into law

- H.R. 1629 would increase the mortgage loan limits for multifamily housing mortgage insurance.

- H.R. 176: FHA Single Family Loan Limit Adjustment Act of 2005 
○ Introduced January 4, 2005; Never passed by House or Senate; Never signed into law

○ H.R. 176 increases the amount that can be insured under FHA mortgages in high-cost areas.

- H.R. 1776: American Homeownership and Economic Opportunity Act of 2000

- Introduced May 12, 1999; Passed by House April 6, 2000; Never passed by Senate; Never signed into law

- H.R. 1776 makes grants available to states and local governments and requires any community development block grant applicant to make an honest effort to reduce barriers to homeownership. The bill extends loan terms for manufactured home lot purchases, lowers down-payment requirements for home purchases, and offers other forms of down-payment assistance for teachers and public safety officers. Hybrid adjustable rate mortgage programs and financial assistance when purchasing homes in high-crime areas are also included.

\section{- H.R. 2589: Mark-to-Market Extension Act of 2001}

○ Introduced July 23, 2001; Passed by House September 24, 2001; Never passed by Senate; Never signed into law

○ H.R. 2589 revises Section 8 and other multifamily housing mortgage assistance programs. For example, vouchers, rent restructuring, "look-back" project eligibility, and housing insurance restructuring programs are included. The mark-to-market program is extended through 2006.

- H.R. 3206: Home Ownership Expansion and Opportunities Act of 2001

○ Introduced November 1, 2001; Never passed by House or Senate; Never signed into law

○ H.R. 3206 permits the Government National Mortgage Association to guarantee securities through the use of certain conventional mortgages.

- H.R. 3755: Zero Downpayment Act of 2004

○ Introduced February 3, 2004; Never passed by House or Senate; Never signed into law

○ H.R. 3755 would permit the Department of Housing and Urban Development to insure single family primary residences for first-time homebuyers who do not make a down-payment. Applicants must participate in mortgage counseling, and in certain circumstances, foreclosure prevention counseling. No more than ten percent of the mortgages held by the Federal Housing Administration may qualify for this program.

- H.R. 4110: FHA Single Family Loan Limit Adjustment Act of 2004

- Introduced April 1, 2004; Never passed by House or Senate; Never signed into law

○ Please see H.R. 176 
- H.R. 5121: Expanding American Ownership Act of 2006

- Introduced April 6, 2006; Passed by House July 25, 2006; Never passed by Senate; Never signed into law

- H.R. 5121 raises the maximum insurable amount of a home to be equal to the full median price of area homes. With regards to FHA mortgage loans, the bill extends the maximum length of the loan from 35 to 40 years and removes the requirement of a three percent down-payment. H.R. 5121 also revises the mortgage insurance premium structure.

- H.R. 5503: FHA Multi Family Loan Limit Adjustment Act

○ Introduced May 25, 2006; Passed by House September 27, 2006; Never passed by Senate; Never signed into law

- H.R. 5503 increases the FHA loan limits in high cost areas for the following types of housing: rental, cooperative, rehabilitation, neighborhood conservation, moderate income, displaced family, condominiums, and housing for the elderly.

- H.R. 5640: American Homeownership and Economic Opportunity Act of 2000

$\circ$ Introduced December 5, 2000; Passed by House December 5, 2000; Passed by Senate December 7, 2000; Signed into law December 27, 2000

- H.R. 5640 affords greater protection to consumers with regards to mortgage insurance cancellations and offers grants to provide downpayment assistance to Section 8 tenants. The bill addresses standards for manufactured homes and eliminates the National Manufactured Home Advisory Council. Programs and services related to rural housing and housing for the elderly or for disabled families are also included.

- H.R. 811: American Dream Downpayment Act

- Introduced April 8, 2003; Passed by Senate November 24, 2003; Passed by House December 8, 2003; Signed into law December 16, 2003

- H.R. 811 amends the Cranston-Gonzalez National Affordable Housing Act and offers down-payment assistance to low-income, first-time home buyers through the use of grants to state and local governments. The bill revises certain criteria for hybrid adjustable rate mortgages and increases the loan limits for FHA multifamily loans.

- S. 1163: FHA Multifamily Housing Mortgage Loan Limit Adjustment Act of 2001

- Introduced July 11, 2001; Never passed by House or Senate; Never signed into law

- S. 1163 increases mortgage loan limits for multifamily housing mortgage insurance.

- S. 1620: Home Ownership Expansion Act of 2001

○ Introduced November 1, 2001; Never passed by House or Senate; Never signed into law 
○ S. 1620 would permit the guaranteeing of conventional mortgage-backed securities.

- S. 2169: PROMISE (Promoting Refinancing Opportunities for Mortgages Impacted by the Subprime Emergency) Act of 2007

- Introduced October 16, 2007; Never passed by House or Senate; Never signed into law

○ S. 2169 gives the Director of the Office of Federal Housing Enterprise Oversight of the Department of Housing and Urban Development authority to suspend, modify or lift the limitation on growth provision in the Fannie Mae Consent Decree and the voluntary temporary growth limitation in the Freddie Mac Letter. The Director also is authorized to increase the mortgage portfolio limitations of both Fannie Mae and Freddie Mac by at least 10 percent. The bill then stipulates that 85 percent of this increase should be set aside for refinancing subprime mortgages that are at risk of foreclosure. The definition of subprime mortgages is at the discretion of the Director.

- S. 3535: Expanding American Homeownership Act of 2006

O Introduced June 19, 2006; Never passed by House or Senate; Never signed into law

- See also H.R. 5121. S. 3535 introduces various changes to conforming loan limits, loan terms, cash investment requirements, mortgage insurance premiums, insurance for condominiums, and insurance for manufactured homes.

- S. 256 Bankruptcy Abuse Prevention and Consumer Protection Act of 2005

○ Introduced February 1, 2005; Passed Senate March 10, 2005; Passed House April 14, 2005; Signed into law April 20, 2005

$\circ$ S. 256 revises the conditions for filing Chapter 7 bankruptcy and includes language to discourage repeat filings and abuse of the bankruptcy system. The bill also outlines penalties for creditor abuse, incorporates means tests for bankruptcy filings, increases the length of time between Chapter 7 bankruptcy filings from six to eight years, and mandates credit counseling for debtors.

- H.R.685: Bankruptcy Abuse Prevention and Consumer Protection Act of 2005

○ Introduced February 9, 2005; Never signed into law

○ See S. 256

- H.R. 975: Bankruptcy Abuse Prevention and Consumer Protection Act of 2003

○ Introduced February 27, 2003; Passed House March 19, 2003; Never signed into law

○ See S. 256

- H.R.975: Bankruptcy Abuse Prevention and Consumer Protection Act of 2003

○ Introduced February 27, 2003; Passed House March 26, 2003; Never signed into law 
○ See S. 256

- S. 1920: Bankruptcy Abuse Prevention and Consumer Protection Act of 2004

- Introduced November 21, 2003; Passed Senate November 25, 2003; Passed House January 28, 2004; Never signed into law

- See S. 256

- H.R. 1529: Involuntary Bankruptcy Improvement Act of 2003

O Introduced April 1, 2003; Passed House June 10, 2003; Never signed into law

o H.R. 1529 amends Federal bankruptcy law so that a court may dismiss false or fraudulent involuntary bankruptcy petitions. The court may also order that consumer reporting agencies remove information pertaining to the bankruptcy petition.

- H.R. 1860: To Amend the Bankruptcy Abuse Prevention and Consumer Protection Act of 2005...

- Introduced April 26, 2005; Never signed into law

- H.R. 1860 amends the Bankruptcy Abuse Prevention and Consumer Protection Act of 2005 to prevent a court from using a means-test as a way to prevent or dismiss a Chapter 7 bankruptcy if the following apply: 1) debtor is currently on active duty and or has returned from active duty within the last 180 days; 2 ) debtor is engaged in some form of homeland security activity (for at least 60 days) or has completed the activity within the last 180 days; 3 ) debtor was in Reserves and called to active duty after September 11, 2001.

- H.R. 2060: To Amend the Bankruptcy Abuse Prevention and Consumer Protection Act of 2005...

O Introduced May 3, 2005; Never signed into law

○ See H.R. 1860.

- H.R. 665: Financial Services Modernization Act

○ Introduced February 10, 1999; Never signed into law

- H.R. 665 permits bank holding companies to participate in any activity that the Federal Reserve Board of Governors and the Secretary of Treasury deem to be financial; subsidiaries of national banks may also participate in financial activities. In addition, the bill outlines cases where a bank holding company may participate in non-financial activities.

- H.R. 1375: Financial Services Regulatory Relief Act of 2004

○ Introduced March 20, 2003; Passed House March 18, 2004; Never signed into law

- H.R. 1375 revises regulations on national bank shareholder elections, capital requirements, and dividend declarations. Furthermore, the bill waives the notice requirement for certain mergers and permits foreign banks at federal agencies to receive deposits from U.S. citizens/residents. 
- Savings associations are offered parity with banks with respect to investment adviser and broker-dealer requirements and they may merge or consolidate with any non-depository institution affiliate. In addition, H.R. 1375 increases to five percent of capital and surplus the amount a savings association may invest in small businesses and removes the percentage of assets limitation on savings associations when making small business loans.

- The bill amends federal law by allowing interest-bearing business accounts. H.R. 1375 revises regulations on interest payments by federal reserve banks and permits a depository institution's reserve ratio to be zero.

- H.R 3951: Financial Services Regulatory Relief Act of 2002

- Introduced March 13, 2002; Never signed into law

○ H.R. 3951 revises requirements for national banks including dividend calculations, voting procedures, requirements for establishing intrastate branches, and capital equivalency deposits for foreign banks. The bill modifies investment and mergers/consolidations regulations for savings associations, offers parity for savings associations, and clarifies the citizenship of federal savings associations. Credit unions may offer 15 year loans and check cashing and money transfer services; furthermore, H.R. 3951 revises credit union governance procedures and securities investment regulations. Depository institutions would have fewer restrictions on interstate mergers.

\section{- S. 2856 Financial Services Regulatory Relief Act}

○ Introduced May 18, 2006; Passed Senate May 25, 2006; Passed House September 27, 2006; Signed into law October 13, 2006

- The Financial Services Regulatory Relief Act (FSRRA) allows the Federal Reserve to pay interest on certain reserve balances of depository banks. The Act reduces reserve requirements from three to 14 percent to zero percent. Provisions pertaining to national banks include simplifying dividend calculations, changing shareholder voting requirements, and expanding banks' abilities to make community development investments.

- S. 2856 offers parity to savings associations. Credit unions may increase the length of the loans they offer from 12 to 15 years and may offer check cashing services to members. With respect to depository institutions, the Act repeals certain reporting requirements on insider lending.

\section{- H.R. 3505: Financial Regulatory Relief Act of 2005}

○ Introduced July 28, 2005; Passed House March 8, 2006; Never signed into law ○ See S. 2856.

\section{Matching Procedure}

The matching of the lobbying and HMDA databases is a tedious task that needs to be done manually using company names. We start with all the companies in the lobbying database and perform a first stage of matching with HMDA based on company names. Then, we go 
through the unmatched companies filing lobbying expense reports one by one manually to mark any mergers and acquisitions (or other events) that might have induced a name change. Once we obtain a list of previous and current names for each company, we apply a secondstage matching based on an algorithm that finds potential matches by searching for common words in the name strings. After the algorithm narrows down the potential matches of lobbying firms among the HMDA lenders, we go through the list one by one once again to determine the right match.

In order to be able to capture the full extent of the lobbying activities carried out by an entity, we meticulously examine the corporate structure of the firms that appear in the lobbying database and that might be matched to particular HMDA lenders based on our algorithm. This is because, in many cases, we encounter firms that are not exactly the same but are linked in a corporate sense. Based on the affiliation between the lobbying company and the matches, we enter the lobbying amounts under four different variables: amount spent by the lender itself, amount spent by the lender's parent company, amount spent by the lender's affiliates, and amount spent by the lender's subsidiary. To illustrate with an example, Countrywide Financial Corp is a bank-holding company that owns Countrywide Home Loans, Inc., Countrywide Bank N.A., Countrywide Mortgage Ventures, LLC, and Countrywide Real Estate Finance. Both Countrywide Financial Corp and Countrywide Home Loans, Inc. report lobbying expenses and all subsidiaries of Countrywide Financial Corp but not the bank-holding company itself, file HMDA information. In this case, we enter the lobbying expense of Countrywide Financial Corp as that of the "parent" in our merged database for all the subsidiaries. The amount spent by Countrywide Home Loans, Inc. is recorded as the lender's own lobbying expense ("self") while the same amount is entered as that of the "sister" for the other affiliates in the HMDA database. Although it is not the case in this example, it is also possible that the firm filing the lobbying expense report might be a subsidiary while the parent company does not appear in the lobbying database but only in the HMDA database. Such cases are recorded in the form of a fourth variable, lobbying expense of the "child". If there are no parent companies or affiliates or subsidiaries or the company itself does not appear in the lobbying database, the corresponding lobbying variable is set to zero. 
Table A1: List of Issues

\begin{tabular}{|c|c|}
\hline Code & Issue \\
\hline $\mathrm{ACC}$ & Accounting \\
\hline $\mathrm{ADV}$ & Advertising \\
\hline AER & Aerospace \\
\hline AGR & Agriculture \\
\hline ALC & Alcohol \& Drug Abuse \\
\hline ANI & Animals \\
\hline APP & Apparel/Clothing Industry/Textiles \\
\hline ART & Arts/Entertainment \\
\hline AUT & Automotive Industry \\
\hline AVI & Aviation/Aircraft/ Airlines \\
\hline BAN & Banking \\
\hline $\mathrm{BNK}$ & Bankruptcy \\
\hline $\mathrm{BEV}$ & Beverage Industry \\
\hline BUD & Budget/Appropriations \\
\hline $\mathrm{CHM}$ & Chemicals/Chemical Industry \\
\hline CIV & Civil Rights/Civil Liberties \\
\hline CAW & Clean Air \& Water (Quality) \\
\hline CDT & Commodities (Big Ticket) \\
\hline $\mathrm{COM}$ & Communications/ Broadcasting/ Radio/TV \\
\hline CPI & Computer Industry \\
\hline CSP & Consumer Issues/Safety/ Protection \\
\hline $\mathrm{CON}$ & Constitution \\
\hline CPT & Copyright/Patent/ Trademark \\
\hline $\mathrm{DEF}$ & Defense \\
\hline DOC & District of Columbia \\
\hline DIS & Disaster Planning/Emergencies \\
\hline $\mathrm{ECN}$ & Economics/Economic Development \\
\hline EDU & Education \\
\hline ENG & Energy/Nuclear \\
\hline ENV & Environmental/Superfund \\
\hline FAM & Family Issues/Abortion/ Adoption \\
\hline FIRE & Firearms/Guns/ Ammunition \\
\hline FIN & Financial Institutions/Investments/ Securities \\
\hline FOO & Food Industry (Safety, Labeling, etc.) \\
\hline FOR & Foreign Relations \\
\hline FUE & Fuel/Gas/Oil \\
\hline GAM & Gaming/Gambling/ Casino \\
\hline GOV & Government Issues \\
\hline HCR & Health Issues \\
\hline $\mathrm{HOU}$ & Housing \\
\hline IMM & Immigration \\
\hline IND & Indian/Native American Affairs \\
\hline INS & Insurance \\
\hline LBR & Labor Issues/Antitrust/ Workplace \\
\hline LAW & Law Enforcement/Crime/ Criminal Justice \\
\hline MAN & Manufacturing \\
\hline MAR & Marine/Maritime/ Boating/Fisheries \\
\hline
\end{tabular}


Table A1: List of Issues

\begin{tabular}{ll}
\hline Code & Issue \\
\hline MIA & Media (Information/ Publishing) \\
MED & Medical/Disease Research/ Clinical Labs \\
MMM & Medicare/Medicaid \\
MON & Minting/Money/ Gold Standard \\
NAT & Natural Resources \\
PHA & Pharmacy \\
POS & Postal \\
RRR & Railroads \\
RES & Real Estate/Land Use/Conservation \\
REL & Religion \\
RET & Retirement \\
ROD & Roads/Highway \\
SCI & Science/Technology \\
SMB & Small Business \\
SPO & Sports/Athletics \\
TAX & Taxation/Internal Revenue Code \\
TEC & Telecommunications \\
TOB & Tobacco \\
TOR & Torts \\
TRD & Trade (Domestic \& Foreign)
\end{tabular}




\title{
Table A2: Lobbying Report Filed by Bear Stearns
}

\begin{tabular}{||ll|}
\hline Clerk of the House of Representatives & Secretary of the Senate \\
Legislative Resource Center & Office of Public Records \\
B-106 Cannon Building & 232 Hart Building \\
Washington. DC 20515 & Washington. DC 20510 \\
\hline
\end{tabular}

\author{
Secretary of the Senate \\ Receired: Feb 04, 2008
}

\section{LOBBYING REPORT}

Lobbying Disclosure Act of 1995 (Section 5) - All Filers Are Required To Complete This Page

1. Registrant Name:

\section{BEAR STEARNS $:$ CO}

2. Addres:

383 MADISON AVE, NEW'YORK, NY 10179

3. Principal place of business (if different from line 2):

4. Contact Name: NANCY LOPEZ

Telephone: 9737932267

E-mail (optional): nancy.lopez(obear.com

Senate ID \#: $5701-12$

House ID \#

7. Client Name: $\mathrm{X}$ Self

\section{TYPE OF REPORT}

8. Year 2007 Midyear [January 1 - June 30):

OR Year End (July 1 - December 31): X

9. Check if this filing amends a previously filed version of this report:

10. Check if this is a Termination Report:

$$
\Rightarrow \text { Termination Date: }
$$

11. No Lobbying Activity:

\section{INCOME OR EXPENSES}

Complete Either Line 12 OR Line 13

\section{Lobbying Firms}

INCOME relating to lobbying activities for this reporting period was:

Less than $\$ 10,000$ :

$\$ 10,000$ or more: $\square \Rightarrow$ Income (nearest $\$ 20,000$ ):

Provide a good faith estimate, rounded to the nearest $\$ 20,000$, of all lobbying related income from the client lincluding all payments to the registrant by any other entity for lobbying activities on behalf of the client].

\section{Organizations}

EXPENSES relating to lobbying activities for this reporting period were:

Less than $\$ 10,000$ :

$\$ 10,000$ or more: $X$ ] $\Rightarrow$ Expenses [nearest $\$ 20,000]$ : $500,000,00$

14. Reporting Hethod.

Check box to indicate expense accounting method. See instructions for description of options.

Hethod A. Fieporting amounts using LDA definitions only

Hethod B. Reporting amounts under section 6033(b)](B) of the Internal Revenue Code

Х) Method C. Reporting amounts under section 162(e) of the Internal Revenue Code 
Registrant Name: BEAR STEARNS \& CO Client Name: Self

\section{LOBBYING ACTIVITY.}

Select as many codes as necessary to reflect the general issue areas in which the registrant engaged in lobtying on behalf of the client during the reporting period. Using a separate page for each code, provide information as requested. Attach additional page[s] as needed.

15. General issue area code: BAN [one per page]

16. Specific lobbying isues:

H.R. 3915 The Mortgage Reform and Anti-Fredatory Lending Act of 2007. Worked to change provision of the legislation related to lending and securitization standards. H.R. 4178 Emergency Mortgage Loan Modfication Act of 2007. A.dvocated the concepts in the proposal but not the proposal.

17. House[s] of Congress and Federal agencies contacted: HOUSE OF REFRESENTATIVES

18. Name of each individual who acted as a lobbyist in this issue area:

Name: DNNEILL, MABYY LYNN

Covered Official Position (if applicable]: N/A

19. Interest of each foreign entity in the specific issues listed on line 16 above. None 


\section{Table A3: Lobbying Report Filed by Citigroup}

00030151177

$\begin{array}{|ll|}\text { Clerk of the House of Representatives } & \text { Secretary of the Senate } \\ \text { Legislative Resource Center } & \text { Office of Public Records } \\ \text { B-106 Cannon Building } & \text { 232 Hart Building } \\ \text { Washington, DC 20515 } & \text { Washington, DC 20510 }\end{array}$

\section{LOBBYING REPORT}

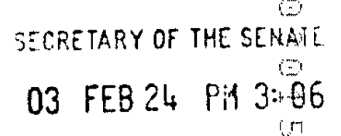

Lobbying Disclosure Act of 1995 (Section 5) - All Filers Are Required to Complete This Page

$\therefore d$

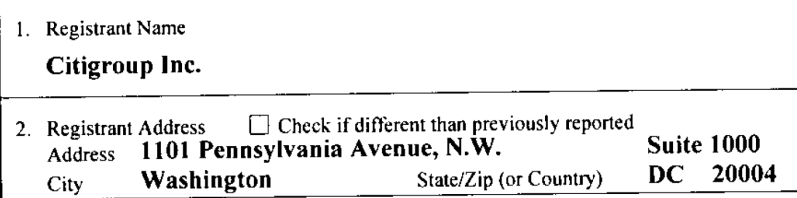

3. Principal Place of Business (if different from line 2)

$\begin{array}{llll}\text { City New York } & \text { State/Lip (or Country) NY } & 10022\end{array}$

\begin{tabular}{|lll|l|}
\hline $\begin{array}{l}\text { 4. Contact Name } \\
\text { Maura Solomon }\end{array}$ & $\begin{array}{l}\text { Telephone } \\
\mathbf{2 0 2 - 8 7 9 - 6 8 2 0}\end{array}$ & $\begin{array}{l}\text { E-mail (optional) } \\
\text { solomonma@citigroup.com }\end{array}$ & $\begin{array}{l}\text { 5. Senate ID \# } \\
\mathbf{3 4 1 9 3 - 1 2}\end{array}$ \\
\hline 7. Client Name $X$ Self & & $\begin{array}{l}\text { 6. House ID \# } \\
\mathbf{3 1 0 5 2 0 0 0}\end{array}$ \\
\hline
\end{tabular}

TYPE OF REPORT 8 . Year $\underline{2002}$ Midyear (January 1-June 30) $\square \quad$ OR $\quad$ Year End (July 1-December 31) $X$

9. Check if this filing amends a previously filed version of this report $\square$

10. Check if this is a Termination Report $\square \gg$ Termination Date

11. No Lobbying Activity $\square$

INCOME OR EXPENSES - Complete Either Line 12 OR Line 13

\section{Lobbying Firms}

INCOME relating to lobbying activities for this reporting period was:

Less than $\$ 10,000$

$\$ 10,000$ or more

$\square>\$$

Income (nearest $\$ 20,000)$

Provide a good faith estimate, rounded to the nearest $\$ 20,000$ of all lobbying related income from the client (including all payments to the registrant by any other entity for lobbying activities on behalf of the client).

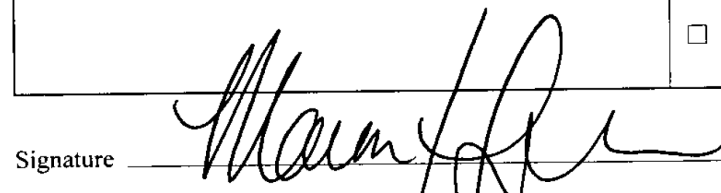

Printed Name and Title
13. Organizations

EXPENSES relating to lobbying activities for this reporting period were:

Less than $\$ 10,000$

$\$ 10,000$ or more $\quad \mathbf{X}>\$$

$\$ 3,040,000.00$

Expenses (nearest $\$ 20,000$ )

14. REPORTING METHOD. Check box to indicate expense accounting method. See instructions for description of options.

\ Method A. Reporting amounts using LDA definitions only

Method B. Reporting amounts under section 6033(b)(8) of the Internal Revenue Code

Method C. Reporting amounts under section 162(e) of the Internal Revenue Code

Date $02 / 14 / 2003$ 
'Registrant Name: Citigroup Inc.

Client Name: Citigroup Inc.

LOBBYING ACTIVITY. Select as many codes as necessary to reflect the general issue areas in which the registrant engaged in lobbying on behalf of the client during the reporting period. Using a separate page for each code, provide information as requested. Attach additional page(s) as needed.

15. General issue area code BAN (one per page)

16. Specific Lobbying issues

H.R. 1009, Business Checking Freedom Act of 2001, (Provisions related to regulatory relief.)

H.R. 1048, Small Business Banking Improvement Act, (Provisions related to regulatory relief.)

H.R. 1051, Predatory Lending Consumer Protection Act of 2001, (Provisions related to high cost mortgages.)

H.R. 1052, Consumer Credit Card Protection Amendments of 2001, (Provisions related to credit card fees.)

H.R. 184, College Student Credit Card Protection Act, (Provisions related to credit cards.)

H.R. 232, Telemarketing Victims Protection Act, (Provisions related to telemarketing.)

H. R. 2572, Gambling ATM and Credit/Debit Card Reform Act, (Provisions related to ATMs.)

H.R. 2572, Gambling ATM and Credit/Debion Cact of 2001, (Provisions related to credit cards.)

H.R. 3215, Combating Illegal Gambling Reform and Moderization Act, (Provisions related to processing payments to Internet gambling sites.)

17. House(s) of Congress and Federal agencies contacted

$\square$ Check if None

Department of Treasury

Executive Office of the President

House of Representatives

Senate

18. Name of each individual who acted as a lobbyist in this issue area

\begin{tabular}{|l|c|c|} 
Name & Covered Official Position (if applicable) & New \\
\hline Andrews, Michael & No \\
\hline Levy, Roger & & No \\
\hline Roberts, Carole & & No \\
\hline Solomon, Maura & & No \\
\hline$-1-2$ & & \\
\hline
\end{tabular}

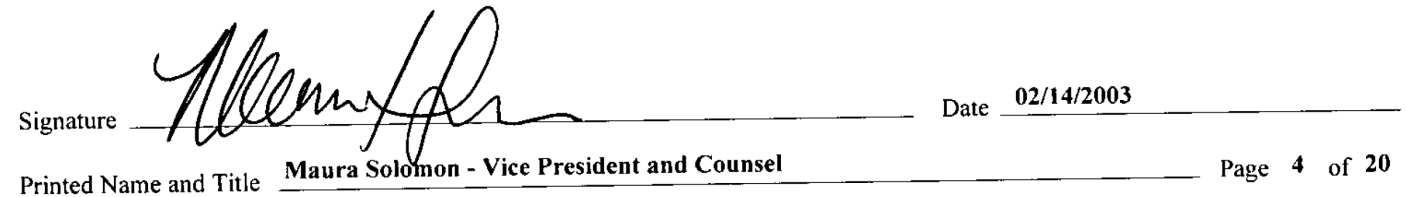


Table A4. Effect of Lobbying on Loan-to-Income Ratio: Additional Robustness Checks

Dependent variable: Loan-to-income ratio at (lender, MSA, year) level

\begin{tabular}{|c|c|c|c|c|c|c|c|}
\hline & $(1)$ & $(2)$ & $(3)$ & (4) & $(5)$ & $(6)$ & (7) \\
\hline & $\begin{array}{l}\text { MSA- } \\
\text { clusters }\end{array}$ & $\begin{array}{c}\text { Drop } \\
\text { outliers }\end{array}$ & $\begin{array}{c}\text { Alternative } \\
\text { measure of } \\
\text { lobbying } \\
\text { expenditures } \\
\end{array}$ & \begin{tabular}{|c|} 
Alternative \\
measure of \\
lobbying \\
expenditures II \\
\end{tabular} & $\begin{array}{c}\text { Scaled } \\
\text { lobbying } \\
\text { expenditures }\end{array}$ & \begin{tabular}{|c} 
Lobbying \\
expenditures \\
(including \\
associations) \\
\end{tabular} & Post-2005 \\
\hline \multirow[t]{2}{*}{ Lobbying expenditures on specific issues (in logs), lagged } & $0.002 * * *$ & $0.002 * * *$ & $0.005 * * *$ & $0.002 * * *$ & $0.008 * * *$ & $0.002 * * *$ & 0.0004 \\
\hline & {$[0.001]$} & {$[0.001]$} & {$[0.001]$} & {$[0.000]$} & {$[0.000]$} & {$[0.001]$} & {$[0.001]$} \\
\hline \multicolumn{2}{|c|}{ Lobbying expenditures on specific issues (in logs), lagged $*$ Dummy $=1$ if year $>=2005$} & & & & & & $0.007 * * *$ \\
\hline & & & & & & & {$[0.001]$} \\
\hline \multirow[t]{2}{*}{ Assets (in logs) } & $0.006^{* * *}$ & $0.004 * * *$ & $0.006^{* * *}$ & $0.006 * * *$ & $0.006^{* * *}$ & $0.006^{* * *}$ & $0.006^{* * *}$ \\
\hline & {$[0.001]$} & {$[0.000]$} & {$[0.000]$} & {$[0.000]$} & {$[0.000]$} & {$[0.000]$} & {$[0.000]$} \\
\hline \multirow[t]{2}{*}{ Market share of lender } & $3.017 * * *$ & $2.032 * * *$ & $3.011 * * *$ & $3.017 * * *$ & $3.019^{* * *}$ & $3.017 * * *$ & $2.999 * * *$ \\
\hline & {$[0.111]$} & {$[0.069]$} & {$[0.090]$} & {$[0.090]$} & {$[0.090]$} & {$[0.090]$} & {$[0.090]$} \\
\hline \multirow[t]{2}{*}{ Average income of loan applicants (in logs) } & $-0.031 * * *$ & $-0.014 * * *$ & $-0.031 * * *$ & $-0.031 * * *$ & $-0.031 * * *$ & $-0.031 * * *$ & $-0.031 * * *$ \\
\hline & {$[0.002]$} & {$[0.001]$} & {$[0.001]$} & {$[0.001]$} & {$[0.001]$} & {$[0.001]$} & {$[0.001]$} \\
\hline Number of observations & 406,035 & 399,984 & 406,035 & 406,035 & 406,035 & 406,035 & \\
\hline R-squared & 0.12 & 0.16 & 0.12 & 0.12 & 0.12 & 0.12 & \\
\hline MSA fixed effects & Yes & Yes & Yes & Yes & Yes & Yes & Yes \\
\hline Year fixed effects & Yes & Yes & Yes & Yes & Yes & Yes & Yes \\
\hline Lender fixed effects & Yes & Yes & Yes & Yes & Yes & Yes & Yes \\
\hline MSA*year fixed effects & Yes & Yes & Yes & Yes & Yes & Yes & Yes \\
\hline
\end{tabular}

The regressions are run on a lender-MSA-year panel. Lobbying on specific issues refers to lobbying on bills and regulations related to mortgage lending and securitization. In column (2), we drop the top and bottom first percentile of loan-to-income ratio and lobbying expenditures. In column (3), lobbying expenditures on specific issues are estimated by an alternative method, namely, by splitting total lobbying expenditures among various issues using share of lobbying reports listing the specific issues as weights. Column (4) uses another alternative measure of lobbying expenditures, which are scaled by a measure of the importance of the law and regulations for which the firm lobbies, giving higher weight to lobbying on bills that appear more often in the lobbying reports. In column (5), lobbying expenditures on specific issues are scaled by the assets of the lender. Column (6) augments lobbying expenditures by the lender with expenditures by associations of which the lender is a member. The lobbying expenditure of associations is split among the members in accordance with the size of the lenders. Column (7) adds a variable that interacts lobbying expenditures with a post-2005 dummy. See text for details. Standard errors denoted in parentheses are clustered at the MSA-level in column (1) and lender-MSA level in columns (2)-(6). ${ }^{* * *},{ }^{* *}$ and $*$ represent statistical significance at 1,5 and 10 percent, respectively. 